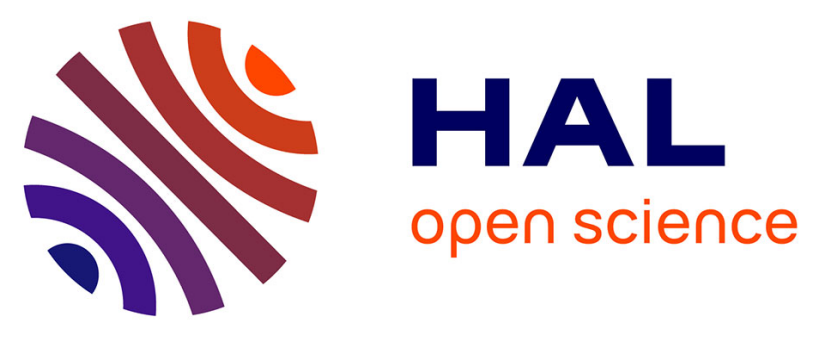

\title{
Temporal variability in phytoplankton pigments, picoplankton and coccolithophores along a transect through the North Atlantic and tropical southwestern Pacific
}

Yves Dandonneau, Yves Montel, Jean Blanchot, Jacques Giraudeau, Jacques

Neveux

\section{To cite this version:}

Yves Dandonneau, Yves Montel, Jean Blanchot, Jacques Giraudeau, Jacques Neveux. Temporal variability in phytoplankton pigments, picoplankton and coccolithophores along a transect through the North Atlantic and tropical southwestern Pacific. Deep Sea Research Part I: Oceanographic Research Papers, 2006, 53 (4), pp.689-712. 10.1016/j.dsr.2006.01.002 . ird-00132021

\section{HAL Id: ird-00132021 https://hal.ird.fr/ird-00132021}

Submitted on 20 Feb 2007

HAL is a multi-disciplinary open access archive for the deposit and dissemination of scientific research documents, whether they are published or not. The documents may come from teaching and research institutions in France or abroad, or from public or private research centers.
L'archive ouverte pluridisciplinaire HAL, est destinée au dépôt et à la diffusion de documents scientifiques de niveau recherche, publiés ou non, émanant des établissements d'enseignement et de recherche français ou étrangers, des laboratoires publics ou privés. 
Temporal variability in phytoplankton pigments, picoplankton and coccolithophores along a transect

through the North Atlantic and tropical southwestern Pacific

By: Yves Dandonneau(1), Yves Montel(2), Jean Blanchot(2), Jacques Giraudeau(3) and Jacques Neveux(4)

(1) IPSL/LOCEAN (CNRS, IRD, MNHN, UPMC), 4 place Jussieu, 75252 Paris cedex 05, France

(2) Centre IRD, BP 172, 97492 Sainte Clotilde, La Réunion

(3) Département de Géologie et Océanographie, UMR CNRS 5805 EPOC, Université de Bordeaux 1, 33405 Talence, France

(4) Laboratoire Arago (UMR 7621), BP 44, 66651 Banyuls sur Mer cedex, France 
Abstract: Biogeochemical processes in the sea are triggered in various ways by chlorophyllcontaining phytoplankton groups. While the variability of chlorophyll concentration at sea has been observed from satellites for several years, these groups are known only from cruises which are limited in space and time. The Geochemistry, Phytoplankton and Color of the Ocean program (GeP\&CO) was set up to describe and understand the variability of phytoplankton composition on large spatial scales under a multi-year sampling strategy. It was based on sea surface sampling along the route of the merchant ship Contship London which travelled four times a year from Le Havre (France) to Nouméa (New Caledonia) via New York, Panama and Auckland. Observations included the measurement of photosynthetic pigments, counts of picoplanktonic cells by flow cytometry (Prochlorococcus, Synechococcus, and picoeucaryotes) and counting and identification of coccolithophores. The results confirmed that tropical areas have low seasonal variability and are characterized by relatively high divinyl-chlorophyll a and zeaxanthin concentration and that the variability is strongest at high latitudes where the phytoplankton biomass and population structure are found to have large seasonal cycles. Thus, the spring bloom in the north Atlantic and an austral winter bloom north of New Zealand are marked by chlorophyll concentrations which are often higher than $0.5 \mu \mathrm{gl}^{-1}$ and by high concentration of fucoxanthin (a pigment used as an indicator for diatoms), while summer populations are dominated by Prochlorococcus sp. and have low chlorophyll concentrations. Apart from this yearly bloom at temperate latitudes, fucoxanthin is scarce, except in the equatorial upwelling zone in the eastern Pacific Ocean, where it is found in moderate amounts. In this region, relatively high chlorophyll concentrations extend generally as far as $14^{\circ} \mathrm{S}$ and do not respond to the seasonal strengthening of the equatorial upwelling during the austral winter. Prochlorococcus, which is known to dominate in oligotrophic tropical seas and to disappear in cold conditions, in fact has its minimum during the spring bloom in the North Atlantic, rather than during the winter. Coccolithophores are ubiquitous, showing a succession of species in response to oceanic conditions and provinces. 19'hexanoyloxyfucoxanthin, the pigment generally considered as an indicator of coccolithophores, is relatively abundant at all times and in all regions, but its abundance is generally not tightly correlated with that of coccolithophores. The regional differences revealed by these results are in overall agreement with Longhurst's division of the ocean into ecological provinces. 


\section{1.- Introduction}

The decades from 1960 to 1980 were marked by an effort of the scientific community to collect large amounts of chlorophyll- $a$ data, which is a bulk indicator of phytoplankton biomass. The first models to simulate biogeochemical fluxes in the global ocean used it to force the process of photosynthetic carbon fixation (Morel, 1991; Platt and Sathyendranath, 1991; Six and Maier-Reimer, 1996). This key process, however, occurs in different ways in a variety of phytoplankton populations that are not randomly distributed, as they need different trophic environments for active growth. Consequently, changes in the phytoplankton community structure depend on the nutrient potential of waters induced by local (sometimes remote) climate conditions and ocean general circulation. Further research, coordinated by the Joint Global Ocean Flux Study, found that this structure has significant biogeochemical consequences. Striking examples are the populations dominated by diatoms, colonial cyanobacteria (Trichodesmium), or calcareous coccolithophores. The diatoms need silica and iron, and under suitable conditions, they make large and dense blooms, after which dead cells sink, transporting large amounts of carbon to depths (Lochte et al., 1993; Romero et al., 2001). Unlike almost all other photoautotrophs, Trichodesmium and some other oceanic cyanobacteria can obtain their nitrogen requirements from abundant dissolved $\mathrm{N}_{2}$. This process, called diazotrophy, is thought to be responsible for a greater drawdown of inorganic carbon in surface oceanic waters than expected if new primary production used only the nitrate supplied by the ocean's dynamics (Karl et al., 1997). The coccolithophores fix carbon in two ways: (1) like other algae, they synthesize organic matter, and (2) they build calcium carbonate tests, which exerts a pressure on the ocean's alkalinity and capacity to dissolve atmospheric carbon dioxide (Robertson et al., 1994). These examples are of intense but episodic events, some of which affect the color of the sea and can be detected from satellites (Subramaniam et al., 2002; Tyrell et al., 1999). Recent models try to account for some of the functional variability of phytoplankton populations by correctly simulating the role of diatoms, nitrogen fixing cyanobacteria, or Prochlorococcus (Bisset et al., 1999; Aumont et al., 2003; Le Quéré et al., 2005). Data used to validate these models come from oceanographic cruises. They are scarce and limited to some regions and seasons. We know very little about the distribution of other small algae such as Chrysophytes, Cryptophytes, Chlorophytes, or small cyanobacteria. Apart from the genera Prochlorococcus and Synechococcus, which can be counted automatically by flow cytometry (Vaulot, 1989), these groups cannot be easily recognized, and direct observation for given locations and seasons is generally lacking. 
However, the algae contain photosynthetic pigments that differ in proportion and sometimes in nature between groups. Inventories of these pigments can help to determine the presence and relative abundance of various phytoplankton groups (Williams and Claustre, 1991; Letellier et al., 1993; Mackey et al., 1996).

The Geochemistry, Phytoplankton and Color of Ocean project (GeP\&CO) was undertaken to describe the time and space variability of phytoplankton populations at the ocean surface in relation with the observed variability of the ocean's physical and chemical conditions (http://www.lodyc.jussieu.fr/gepco). Measurements of photosynthetic pigments collected four times a year during twelve GeP\&CO cruises from Europe to the southwestern tropical Pacific (Table 1) reflect the various assemblages of phytoplankton and their seasonal and regional changes. These long transects across such contrasted areas as the North Atlantic, the Caribbean Sea, the equatorial Pacific and the south subtropical Pacific are of global interest. Pigment data are complemented by counts of picoplankton and coccolithophores and by nutrient measurements. This article describes the main patterns of variability encountered during GeP\&CO and discusses them in relation to ancillary data such as temperature and nutrients. It focuses on the phytoplankton groups mentioned above, which have a specific impact on the biogeochemistry of the ocean and on their main diagnostic pigments. The work was organised according to Longhurst's (1998) classification of ecological oceanic provinces, which is a recent synthesis of modern knowledge. GeP\&CO is part of the PROcessus Océaniques et Flux (PROOF) program, which is the French contribution to JGOFS. Financial support was provided by the French research institutes INSU/CNRS, IRD, CNES and IFREMER. 


\section{Material and methods}

\subsection{Sampling conditions at sea}

The GeP\&CO surveys (Fig. 1) were undertaken from a merchant ship, Contship London, during its regular crossings. A cabin on the main deck was made available to the GeP\&CO experiment, for filtering seawater and conditioning and storing samples. Seawater samples were taken every 4 hours (i. e. at 6:00, 10:00, 14:00, 18:00 and 22:00, local time; sampling at 2:00 was skipped). Seawater samples were drawn from the outlet of a thermosalinograph (http://www.legos.obs-mip.fr/umr5566/francais/obs/sss/) installed in the engine room at the intake of the cooling system, at a depth of approximately $5 \mathrm{~m}$, depending on the ship's load. A high flow rate (several $\mathrm{m}^{3} \mathrm{~min}^{-1}$ ) minimizes heating and contamination and thus ensures high quality water for chemical and biological analyses. Each cruise lasted about 38 days, from Le Havre (France) to Nouméa (New Caledonia). Samples were stored on board for another 45 days until the ship returned to Le Havre. Then, it took from one week to two months before laboratory measurements were taken. Storage thus generally lasted between 50 days for samples that were taken just before the call at Nouméa and then quickly processed in the laboratory and 140 days when processing of samples from the eastern North Atlantic was delayed for about two months. All samples were stored at $-80^{\circ} \mathrm{C}$, in order to preserve their biological and optical properties (Sosik, 1999).

\subsection{Nutrients}

Seawater samples ( of $20 \mathrm{ml}$, in polyethylene tubes, with an addition of mercury chloride, kept frozen at $-80^{\circ} \mathrm{C}$ until analysis) were processed on a 4 channel Technicon AAII analyzer. The process for determining phosphate, nitrate (nitrate + nitrite minus nitrite) and silicate concentration used the same reactions as in Strickland and Parsons (1972). Final concentrations $(\mu \mathrm{g} / \mathrm{l})$ were calibrated in relation to reference material of $\mathrm{NO}_{2}, \mathrm{NO}_{3}, \mathrm{PO}_{4}$ and $\mathrm{Si}(\mathrm{OH})_{4}$.

\subsection{Measurements of photosynthetic pigments using HPLC}

Seawater samples were filtered through Whatman GF/F filters, $25 \mathrm{~mm}$ in diameter, with a vacuum pressure of less than 0.25 atm. Filtering was stopped after one hour, in order to 
avoid damage to the pigments that may occur when filters are clogged and filtration takes too long. Degradation of some chlorophyll-a into chlorophyllide (Jeffrey and Hallegraeff, 1987) and also pheopigments (Suzuki and Fujita, 1986) could occur during filtration and sometimes within the cells before being affected by added solvent (Neveux, 1988). A filtration time of one hour is a compromise between the risk of degradation and the need of enough pigments for a precise measurement. The volume filtered under such conditions is usually about 2.5 or 3 liters in clear waters and sometimes only 1.5 liters in rich coastal waters. Chlorophyllides were not measured in our samples. However, chl $a$ estimates made by HPLC and spectrofluorometry were in good agreement, which suggests that degradation of Chl $a$ into chlorophyllide $a$ was negligible. Furthermore, phaeopigments were most often found in negligible quantities. Filters were then folded with the phytoplankton cells inside, inserted into a numbered plastic envelope and stored at $-80^{\circ} \mathrm{C}$. They were recovered at the next call in Le Havre and transported to LOCEAN in Paris and later to the Station Marine d'Arcachon in containers packed with dry ice.

Measurements were made according to the Goericke and Repeta (1993) method with the high-performance liquid-chromatography equipment of the Laboratoire d'Océanographie Biologique in Arcachon. This equipment, a Thermo Separations HPLC system, has a binary pump, a $3-\mu \mathrm{m}$ pore size Licospher (endcapped) C- 8 column, $250 \times 4 \mathrm{~mm}$, maintained at $30^{\circ} \mathrm{C}$ and a Thermo Separations UV LP 6000 diode array detector. A refrigerated automat can handle several samples, thus allowing measurements to be taken at night. Filters were extracted in $2 \mathrm{ml}$ of $100 \%$ methanol for 1 hour at $4{ }^{\circ} \mathrm{C}$ in darkness after ultrasonication $(15 \mathrm{~s})$. Extracts were filtered through $0.2-\mu$ PTFE filters to remove all solid particles and then loaded into the automat at $2{ }^{\circ} \mathrm{C} .1 \mathrm{M}$ ammonium acetate $(2: 1, \mathrm{v} / \mathrm{v})$ was added just prior to injection. Pigments were separated at a flow rate of $0.6 \mathrm{ml} / \mathrm{min}$. The proportion of solvents varies linearly during the separation, programmed as follows (the three values are respectively for time given in minutes, \% solvent A, \% solvent B): $(0 ; 75 ; 25),(1 ; 50 ; 50),(20 ; 30 ; 70)$, $(25 ; 0 ; 100),(35 ; 0 ; 100),(40 ; 75 ; 25)$. Solvent A consists of $70 \%$ methanol and $30 \%$ ammonium acetate $(1 \mathrm{M})$ and solvent B of $100 \%$ methanol. The column was then restored to original conditions for $10 \mathrm{~min}$. Pigments were detected by absorption at $440 \mathrm{~nm}$.

Numeric chromatograms were recorded and processed with the PC1000 Thermo Separations software. Calibration used pigment standards purchased from DHI Water and Environment, Horsholm, Denmark: peridinin, 19'butanoyloxyfucoxanthin (19'BF), 
fucoxanthin, 19'hexanoyloxyfucoxanthin (19'HF), prasinoxanthin, violaxanthin, diadinoxanthin, zeaxanthin, chlorophyll $b(\mathrm{Chl} b)$, divinyl-chlorophyll $a$ (d-Chl $a$ ), chlorophyll $a(\mathrm{Chl} a$ ) and $\beta$ carotene. As we had no standard of divinyl chlorophyll $b$ (d-Chl $b$ ), we identified its peak in the chromatogram according to its relative position in the Goericke and Repeta (1993) method, and we estimated its concentration by assuming that its extinction coefficient was identical to that of $\mathrm{Chl} b$. However, separation of d-Chl $b$ (or d$\mathrm{Chl} a$ ) from $\mathrm{Chl} b$ or $(\mathrm{Chl} a)$ was often uncertain and entailed errors.

\subsection{Spectrofluorometric measurements of chlorophyllous pigments}

Filtration and filter storage were done in the same way as above for the HPLC measurements, the main difference being that the filtered volume was only half a litre, which usually took less than 10 minutes, thus minimizing pigment degradation. Measurements were taken at LOCEAN in Paris with a F-4500 Hitachi spectrofluorometer. Filters are first ground in $10 \mathrm{ml}$ glass tubes with $6 \mathrm{ml}$ of $90 \%$ acetone with a scratched glass rod, and extraction is allowed overnight at $2{ }^{\circ} \mathrm{C}$ in darkness. The extracted contents of each tube were centrifuged, then $1 \mathrm{ml}$ was transferred to a square $1 \mathrm{~cm} \times 1 \mathrm{~cm}$ quartz cell and fluorescence emission excitation spectra were measured in the spectrofluorometer, operating in ratio mode. The measurement process was parameterized as follows: the excitation wavelength varied from 390 to $480 \mathrm{~nm}$, with a $3-\mathrm{nm}$ step and excitation slit adjusted to $5 \mathrm{~nm}$, and emission was measured from 620 to $720 \mathrm{~nm}$ in steps of $4 \mathrm{~nm}$, with an emission slit adjusted to $10 \mathrm{~nm}$. This yielded $31 \times 26=806$ fluorescence measurements for each sample.

The concentration of chlorophyllous pigments was then computed according to Neveux and Lantoine (1993), given that each one of these 806 fluorescence values is the sum of the contribution of $n$ distinct pigments, with unknown concentrations $C_{1}, C_{2} \ldots C_{n}$. The solution is given by the $C_{i}$ values that minimize:

$$
Q^{2}=\sum_{\lambda_{e x c}=390}^{480} \sum_{\lambda_{e n}=620}^{720}\left(F_{\lambda_{e c}, \lambda_{e n}}-\sum_{i=1}^{n} C_{i} F_{i, \lambda_{e c}, \lambda_{e n}}^{*}\right)^{2}
$$

where $F$ is the fluorescence of the sample at wavelengths $\lambda_{e x c}$ and $\lambda_{e m}$, and $F_{i}^{*}$ is the specific fluorescence of pigment $i$ (fingerprint) determined on pigment standards. The main improvement to the method first described by Neveux and Lantoine (1993) is an increase in the number of fluorescence measurements, of which there are now 806 instead of 24, thus 
discriminating more efficiently between pigments whose emission-excitation fluorescence spectra differ only slightly.

We used $n=13$ pigments: Chl $a, \mathrm{Chl} b$, chlorophyll $c_{2}$, chlorophyll $\mathrm{c}_{3}, \mathrm{~d}-\mathrm{Chl} a, \mathrm{~d}-$ $\mathrm{Chl} b$, corresponding phaeopigments and a fictitious pigment with a flat fluorescence excitation-emission spectrum that accounts for the background signal and turbidity of the extract. Numerically minimizing $Q^{2}$ by linear least squares approximation sometimes gave small negative concentrations for some pigments. In such cases, these pigments were set to a null concentration, and the computation was repeated without them until only positive concentrations are found. The measurements were calibrated with pigment standards purchased from DHI Water and Environment, Horsholm, Denmark. The d-Chl $b$ was prepared, isolated and quantified by Jacques Neveux.

\subsection{HPLC vs spectrofluorometric determination of chlorophyllous pigments}

Chlorophyllous pigments were thus estimated in parallel by HPLC and by spectrofluorometry. The two techniques should give unbiased estimates since they both discriminate the various pigments and are calibrated in relation to the same standards. Both subsets are included in the GeP\&CO database. Comparative tests of 24 duplicate samples from a GeP\&CO cruise, that were shared with Hervé Claustre at the Laboratoire d'Océanographie de Villefranche (LOV) showed tight relationships between our HPLC measurements of carotenoids and their estimates. However, it became obvious that the GeP\&CO HPLC measurements of d-Chl $a$ were inconsistent and did not reproduce the major trends that one might expect from a large scale survey, such as high \%d-Chl $a$ in oligotrophic areas or in summer in temperate regions. Indeed, the GeP\&CO HPLC determinations of d-Chl $a$ showed no correlation with those made at LOV (Fig. 2a). On the contrary, the GeP\&CO spectrofluorometric determinations of d-Chl $a$ were in close agreement with those made at LOV (Fig. 2a: $\mathrm{r}^{2}=0.93$, slope $=1.17$ ). There was also a close agreement between the GeP\&CO spectrofluorometric and the LOV HPLC determinations of Chl $a$ (Fig. $2 \mathrm{~b}: \mathrm{r}^{2}=0.98$, slope $=1.07)$. The problem arose from an imprecise separation of Chl $a$ and d-Chl $a$ in the GeP\&CO HPLC instrumentation and method. In principle, the Goericke and Repeta method separates these two pigments. In fact, in our chromatograms, the two absorption peaks were more or less mingled and accurate separation was not possible. This problem did not affect the measurement of carotenoid pigments. Consequently, for chlorophyllous pigments, we 
prefer here to use the GeP\&CO spectrofluorimetric determinations. Total chlorophyll $a$ (Tchl$a)$, which is the sum of Chl- $a$ and d-Chl- $a$, as well as the percentage of $\mathrm{d}-\mathrm{Chl} a(\% \mathrm{dChla}=$ $\left.100 \times \mathrm{d}-\mathrm{Chl} a(\mathrm{Chl} a+\mathrm{d}-\mathrm{Chl} a)^{-1}\right)$, are computed from the spectrofluorometric determinations. The effects on our results should be small, given their tight agreement with the HPLC estimates made at LOV.

\subsection{Partitioning total chlorophyll a into size categories using pigments concentrations}

The size structure of the planktonic community has a strong influence on the export of particulate organic carbon to depth (Boyd and Newton, 1995), and some global biogeochemical models (Aumont et al., 2003) include small and large phytoplankton in order to better represent this export. In addition, the optical properties of the phytoplankton are also a function of the average size of planktonic cells (Bricaud et al., 2004). Knowledge of the size structure of the phytoplankton is thus useful to predict the efficiency of the biological carbon pump, to validate biogeochemical models, and to understand the variability of sea color. Such knowledge, however, is difficult to obtain routinely at sea. Quantitative pigment inventories provide a guess at this size structure, by using pigments that indicate phytoplankton groups (Vidussi et al., 2001). The basic assumptions are as follows :

- fucoxanthin and peridinin are diagnostic pigments for diatoms and dinoflagellates, which dominate the microplankton $(>20 \mu \mathrm{m})$,

- nanoplankton $(2-20 \mu \mathrm{m})$ is characterized by alloxanthin, 19'BF and 19'HF, which are abundant in most microflagellates,

- picoplankton $(<2 \mu \mathrm{m})$ is assessed from zeaxanthin and Tchlb.

Estimations of percentages of each size category were made with weighting coefficients (Bricaud et al., 2004), determined empirically, that maximize the correlation coefficient between the weighted sum of these seven pigments (DPw) and Tchla, in order to account for differences in diagnostic-pigments to $\mathrm{Chl} a$ ratios in phytoplankton classes:

$$
\begin{array}{ll}
\% \text { Pico }(<2 \mu) & =100 \times(0.86 \mathrm{Zea}+1.01 \mathrm{Tchlb}) / \mathrm{DPw} \\
\% \text { Nano }(2 \mu<. .<20 \mu) & =100 \times\left(1.2719^{\prime} \mathrm{HF}+0.3519^{\prime} \mathrm{BF}+0.6 \text { Allo }\right) / \mathrm{DPw} \\
\% \text { Micro }(>20 \mu) & =100 \times(1.41 \mathrm{Fuco}+1.41 \mathrm{Peri}) / \mathrm{DPw}
\end{array}
$$


where DPw $=0.86$ Zea +1.01 Tchlb $+1.2719^{\prime} \mathrm{HF}+0.3519^{\prime} \mathrm{BF}+0.6$ Allo +1.41 Fuco + 1.41 Peri.

We did not consider alloxanthin, which was not measured on cruises 1 to 4 . This probably does not change the results much, as alloxanthin concentration is generally lower than that of 19'HF or 19'BF by a factor 10 or 20, except in some coastal areas, which were not considered in this work. Allocating Tchlb, which is present in large nanoplanktonic chlorophytes, to the picoplankton may lead to errors. However, $\mathrm{Chl} b$ and $\mathrm{d}-\mathrm{Chl} b$ occur mainly at depth and have a very small impact on the present estimates of picoplankton, since their concentration in the GeP\&CO surface samples is small. There are certainly many exceptions to these pigment/size relationships, such as the tiny diatoms Chaetoceros socialis and Nitzschia spp., or zeaxanthin containing microplanktonic Trichodesmium, or 19'BF and 19 'HF present in golden-brown flagellates of picoplanktonic size. Allocating one pigment to a class of algae may also lead to errors (see fucoxanthin for diatoms and 19'HF for coccolithophorids in the discussion section). This approach corresponds to generally admitted properties of algal groups (Jeffrey et al., 1997) and is only intended to provide the dominant trends at the regional and seasonal scales.

\subsection{Flow cytometry counts of picoplankton}

1.5-ml seawater samples in cryotubes were preserved with $1 \%$ glutaraldehyde, and after 15 minutes they were stored at $-80^{\circ} \mathrm{C}$ to await laboratory analysis. The flow cytometry measurements were performed within two hours after thawing on $0.1 \mathrm{ml}$ water volumes with a FACScan flow cytometer (Becton-Dickinson) equipped with two light scatter sensors (right angle and forward angle) and three fluorescence sensors (green, orange and red). Filtered seawater served as a sheath fluid and $1 \mu \mathrm{m}$ fluorescent beads were used as standards (Blanchot and Rodier, 1996). The data were treated with the Becton-Dickinson LYSYS II software and analysed with the cytowin software (Vaulot, 1989) to identify and count Prochlorococcus spp. (low forward angle diffusion, relatively low red fluorescence, null orange fluorescence), Synechococcus spp. (orange fluorescence, medium red fluorescence, forward and right angle diffusion) and undifferentiated phytoplanktonic picoeucaryotes (hereafter referred to as picoeucaryotes, high red fluorescence, high diffusion, null orange fluorescence). Under high irradiance conditions, Prochlorococcus cells often had red fluorescence that was too weak and were not detected. In such environments, low counts of this species do not necessarily mean 
that it is not abundant. Hence, we shall not consider these results here and will describe the variability of Prochlorococcus spp. using only the abundance of its specific pigment d-Chl $a$

\subsection{Counts of coccolithophores}

1.5 L of seawater was filtered onboard through Millipore nitrocellulose AA filters (0.8- $\mu$ pore size, $25-\mathrm{mm}$ diameter). The filters were then stored in flat circular biopsy boxes and kept dry while awaiting identification and counting. Intact coccospheres were counted under a polarized optical microscope, with a magnification of 1250 , according to the procedure of Giraudeau and Bailey (1995). The taxonomic composition of the coccolithophore population and total standing stocks expressed in cells $/ \mathrm{ml}$ was obtained after counting of the specimens in a minimum of 30 view-fields, extrapolating the counted specimens to the entire effective filtration area and correcting for the volume of filtered seawater.

\section{Results}

The data collected during the $12 \mathrm{GeP} \& \mathrm{CO}$ cruises (Table 1) cover several oceanic regions. We organized here the large set of measurements according to the division of the ocean into oceanic provinces. We adopted the limits proposed by Longhurst (1998) for the 'North Atlantic Drift' (NADR), for the 'Gulf Stream' (GFST), for the 'Caribbean' (CARB) and for the 'Archipelagic Deep Basins' $(\mathrm{ARCH})$ provinces while changing the other ones slightly:

- we fixed the limit between the 'Pacific North Equatorial Current' (PNEC) and the 'Pacific Equatorial Divergence' (PEQD) provinces at $2^{\circ} \mathrm{N}$, instead of $5^{\circ} \mathrm{N}$, basing it on a higher sea surface temperature (SST) which characterizes PNEC and extends as far southward as $2^{\circ} \mathrm{N}$,

- we extended PEQD farther south than $5^{\circ} \mathrm{S}$, as suggested by relatively high chlorophyll and nutrient concentrations and $\mathrm{CO}_{2}$ partial pressure southward to $12^{\circ} \mathrm{S}$ (Dandonneau and Eldin, 1987; Dandonneau, 1995),

- we discarded the region between $12^{\circ} \mathrm{S}$ and $16^{\circ} \mathrm{S}$, which is episodically influenced by the equatorial upwelling (Dandonneau and Eldin, 1987) or by the Tahiti island mass and thus 
is not always subject to the oligotrophic regime that prevails in the 'South Pacific Subtropical Gyre Province' (SPSG),

- similarly, we discarded the region of SPSG south of $30^{\circ} \mathrm{S}$, where perturbations of oceanic currents induced by New Zealand islands and vertical mixing consecutive to winter cooling give different conditions to that of SPSG.

- furthermore, we discarded all observations that were close to the coast (in the English Channel, along the east coast of North America, near Panama and near New Zealand) or collected in a transition zone.

All these provinces represent different regimes of upper mixed layer formation and seasonal cycles of phytoplankton growth and the many conditions that may be encountered in the world ocean. Finally, 980 out of the total of 1,500 observations of the GeP\&CO program were retained (Fig. 1).

We used quarterly observations made from November of 1999 to August of 2002 and we computed the average observations in each province for each cruise (phytoplankton pigments, nutrients, counts of picoplankton: Figs 4,5 to 7 and 9 to 11). The abundance of coccolithophores (cell numbers, averaged) was also described in the oceanic provinces listed above with the exception of the CARB and ARCH provinces, for which coccolithophore counts have not yet been processed; data described here are limited to one seasonal cycle (GeP\&CO A to D). An additional dataset related only to the Pacific was computed to provide information on interannual variability in coccolithophore standing stocks and diversity within a single season (boreal fall 1999, 2000 and 2001, corresponding to the GeP\&CO cruises A, E and I).

\subsection{North Atlantic Drift province}

Phytoplankton pigment and nutrient concentrations revealed a high seasonal variability in this province (Fig. 3). The maximum each year occurs in the boreal spring for Tchla which amounts to $1 \mu \mathrm{g} 1^{-1}$. During the year 2000, however, the spring bloom was weak in late April on the GeP\&CO_cruise C and fucoxanthin (a proxy for diatoms, which generally characterize the spring bloom) was still abundant in summer, suggesting that the bloom occurred late during that year or was partly overlooked, considering the low sampling frequency. The spring bloom was marked by high fucoxanthin content, high contribution of 
the microplankton to phytoplankton biomass (30 to $50 \%$ ), relatively low contribution of picoplankton (despite relatively high numbers of picoeucaryotes) and low abundance of Prochlorococcus as suggested by low $\% \mathrm{dChl} a$. The highest $\% \mathrm{dChl} a$ was found in autumn each year. The contribution of nanoplankton to phytoplankton biomass varied between 30 and $60 \%$. Coccolithophore cells were equally abundant during spring and summer 2000 (ca. 80 cells $\mathrm{ml}^{-1}$ ), though composed of different species (Fig. 4): a heavily calcified morphotype of Emiliania huxleyi ("closed" E. huxleyi) which has been reported previously only in the Bay of Biscay (Beaufort and Heussner, 2001), dominated the spring 2000 population in the NADR province. Nutrients peaked in winter, after convective mixing with deep waters, except in January 2002, when winter mixing had not yet brought nutrient concentrations to the levels of 2000 or 2001. All major nutrients were generally exhausted in summer, but silicates still remained at the surface $\left(1.5 \mu \mathrm{mol}^{-1}\right)$ in July and October of 2001.

\subsection{Gulf Stream}

Our observations in this province clearly corresponded to what is expected in temperate regions, with a clear Tchla maximum in spring of about $1.5 \mu \mathrm{g} \mathrm{l}^{-1}$ and a minimum in summer or autumn (Fig. 5). The spring maximum corresponded to a maximum of fucoxanthin and, in most cases, of picoeucaryotes. Microplankton contributed to more than $50 \%$ of this maximum. \%dChla was null in winter and spring and culminated in summer or autumn (25 to $30 \%$ ). Zeaxanthin and \% Pico were at a maximum when temperature was high, in summer or autumn. Nanoplankton accounted for about $25 \%$ of the phytoplankton throughout the sampled period, which was a smaller value than in NADR. The abundance of some of the largest contributors to nanoplankton, the coccolithophores, seems to have been particularly intense during the microplankton-dominated spring season, peaking to 130 cells $\mathrm{ml}^{-1}$ in the spring of 2000 (Fig. 4). This average value was, so far, the highest recorded in the GeP\&CO coccolithophore dataset. Nutrient concentrations culminated in winter or spring, with maxima of only $4 \mu \mathrm{M}$ for nitrate (compared to 6 in NADR).

\subsection{Carribbean Sea}

In this province, sea-surface temperature is higher than $25^{\circ} \mathrm{C}$ all year round, with a maximum in May (Fig. 6), and nutrient conditions are oligotrophic. Tchla has always been very low there, averaging $0.13 \mu \mathrm{g}^{-1}$, and the seasonal cycle is uncertain (Fig. 6). Fucoxanthin 
was practically non-existent, except on one occasion, in early May 2000, when its relative abundance might indicate an episode of microplankton growth. \%dChl $a$ was about 30 to $40 \%$ and zeaxanthin was relatively high, averaging $0.06 \mu \mathrm{g} \mathrm{l}^{-1}$. The picoplankton always dominated, and its contribution to total phytoplankton biomass was greater than $60 \%$ (except in May 2000). Nutrient concentration was low for all 12 cruises. Numbers of picoeucaryotes were less than 1000 cells $1^{-1}$ most of the time, while those of Synechococcus fluctuated between 1000 and 10 000, with no clear seasonal signal.

\subsection{Pacific North Equatorial Countercurrent}

As for the CARB province, the sea surface temperature was higher than $25^{\circ} \mathrm{C}$ all year round, with a maximum in May (Fig. 7). Tchla averaged $0.27 \mu \mathrm{gl}^{-1}$, in which 10 to $40 \%$ was due to d-Chl $a$. Nanoplankton and microplankton were more abundant than in CARB, as indicated by fucoxanthin in detectable amounts most of the time. Coccolithophore populations steadily increased from 20 to 40 cells ml$^{-1}$ between November 1999 and August 2000 (Fig. 8) and were overwhelmingly dominated by the Gephyrocapsa oceanica. Boreal autumn appears to be the season with the lowest abundance for this group as depicted by the steadily low total standing stocks recorded in October-November 1999, 2000 and 2001. Zeaxanthin, which characterizes picoplankton, was almost $0.1 \mu \mathrm{g} 1^{-1}$. The picoplankton represent about 50 to $60 \%$ of total phytoplankton biomass. Synechococcus was ten times more abundant than eukaryotic picoplankton. Nutrient concentration was generally low, though non null. However, nitrate concentration was higher than $2 \mu \mathrm{M}$ in April 2001 and July 2002.

\subsection{Pacific Equatorial Divergence}

In this province, the equatorial upwelling brings high nutrient concentrations to the surface (nitrate and silicate concentrations are respectively about 6 and $2.6 \mu \mathrm{M}$ ). However, the Tchla average was only $0.19 \mu \mathrm{g}^{-1}$ (Fig. 9) and the maximum did not exceed $0.21 \mu \mathrm{g}^{-1}$. These waters are well known as High-Nutrients Low-Chlorophyll waters (HNLC). Phytoplankton biomass is dominated by the picoplankton (about $50 \%$ ) and by the nanoplankton (30\%), while microplankton never exceeded $25 \%$. Fucoxanthin had a low concentration indeed, around $0.01 \mu \mathrm{g}^{-1}$. Picoeucaryotes varied by a factor of 4 , and their maximum in the boreal spring of 2001 was not detected in the Tchla record. 
Sea-surface temperature exhibited a slight but clear seasonal cycle during the sampled period (during which no El Niño occurred), with a maximum in April and a minimum in August and November. However, this seasonal cycle had no or little effect on other properties: Tchla, d-Chl $a$, Fuco, Zea, \% Micro, \% Nano- and \% Pico remained remarkably steady all the year round. The exceptions were coccolithophores, which showed a clear

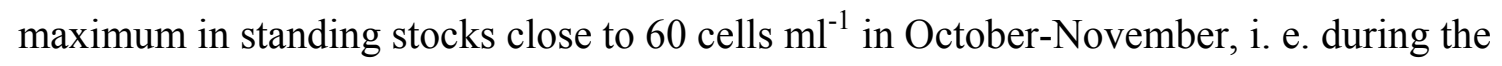
period of maximum upwelling in the PEQD province (Fig. 8). The coccolithophore populations were moderately diverse and were dominated by the opportunistic and occasionally blooming species E. huxleyi.

\subsection{South Pacific Subtropical Gyre}

In this province (Fig. 10), highly oligotrophic conditions affected all the variables of the ecosystem: Tchla was low all year round (average $=0.07 \mu \mathrm{g} \mathrm{l}^{-1}$, maximum $=0.12 \mu \mathrm{g}^{-1}$ in July 2002), and \%dChl $a$ was always greater than 30. Fucoxanthin was found to have very low concentrations, while the zeaxanthin average was $0.04 \mu \mathrm{g}^{-1}$, so that the picoplankton ( $\sim 75 \%)$ strongly dominated the microplankton ( $\sim 10 \%)$. Nanoplankton only contributed to total phytoplankton biomass by $\sim 15 \%$ in general. Sea-surface temperature was at a minimum in July and at a maximum in January. Tchla also followed a low-amplitude seasonal cycle, in opposition to that for temperature. Coccolithophore standing stocks hardly went beyond 20 cells $\mathrm{ml}^{-1}$, with the maximum and minimum values occurring, as in the PNEC province, during the boreal summer and autumn, respectively (Fig. 8). The computed average values for the successive 1999, 2000 and 2001 October-November periods pointed to a steady increase in coccolithophore standing stocks.

\subsection{Archipelagic Deep Basins}

This province is located at about the same latitude as the previous one, and nutrient concentrations are low all the year and do not exhibit strong seasonal variations. However, there are clearly seasonal variations for all biological variables. In the austral winter (August), we observed maxima in Tchla concentration (August: $0.27,0.23$ and $0.49 \mu \mathrm{g} \mathrm{l}^{-1}$ in 2000, 2001 
and 2002), fucoxanthin and nanoplankton and microplankton percentage (total 50\%) when the sea surface temperature was at minimum. Prochlorococcus represented $20 \%$ of Tchla. In the austral summer (January), the proportion of Prochlorococcus increased to $40 \%$ of Tchla, which was then at its minimum $\left(0.09,0.07\right.$ and $\left.0.08 \mu \mathrm{g}^{-1}\right)$, and total picoplankton reached $75 \%$. \%dChla mirrored exactly the variations of Tchla (Fig. 11). Synechococcus were occasionally very abundant (in December 1999, August 2000 and May 2001).

\section{Discussion}

Although the sampling frequency was relatively low, the Gep\&CO observations from 1999 to 2002 covered a wide range of oceanic conditions, and the data collected reflect some of the changes in the physical and chemical forcing and in the phytoplankton community structure. These data showed seasonal variability in various provinces. They also made it possible to formulate a wide range of questions on how the composition of the phytoplankton responds to the variability of the ocean.

\subsection{Nutrient - chlorophyll relationship}

Nitrate, phosphate and silicate have long been considered to be the main limiting nutrients for primary production. In agreement with this statement, the nitrate exhausted SPSG had a very low chlorophyll concentration (Figure 10), while the highest chlorophyll records in the GeP\&CO data were for the North Atlantic in spring, coincident with high nitrate concentration (Figs 3 and 5).

However, the highest nitrate concentrations encountered during the whole experiment were not in the North Atlantic, but rather in PEQD, where they were associated with chlorophyll concentrations that barely exceeded $0.2 \mu \mathrm{g} \mathrm{l}^{-1}$ (Fig. 9). The High Nutrients - Low Chlorophyll (HNLC) character of the equatorial Pacific has long been known (Thomas, 1979; Dugdale and Wilkerson, 1991). This anomaly is now explained by lack of iron in this area, which is remote from continental sources (Martin, 1992; Gordon et al., 1997). Grazing may also play an important role (Landry et al., 1997; Le Borgne et al., 2003). Strong limitation of phytoplankton growth in PEQD is especially obvious on a Tchla vs nitrate scatterplot (Fig. 12) for which nitrate concentrations observed during GeP\&CO were markedly higher in this 
province than in any other. By comparison, the North Atlantic in winter had similar or often larger chlorophyll concentrations (Figs 3 and 5) in spite of severe light limitation caused by short days, cloud coverage and a deep mixed layer. The HNLC character of the equatorial Pacific contrasted with all other provinces described here. The neighbouring PNEC region had lower nitrate content, but chlorophyll was higher on average (Figs 7 and 9). Iron input from river outflows in this low-salinity province may explain the difference between the two areas.

\subsection{Seasonal variability}

The regions for which seasonality in chlorophyll concentration was most strongly marked are those in the temperate North Atlantic: NADR and GFST. In our GeP\&CO data, these two provinces looked very similar, in terms both of the phase of the seasonal cycle and of the magnitudes of the variables. The patterns of seasonal variability corresponded to the well-known succession of events that occurs each year in temperate regions. Nutrients were high in winter (January), while Tchla was only $0.2 \sim 0.3 \mu \mathrm{g}^{-1}$ in NADR, as expected when irradiance is low and the mixed layer is deep, but was near $1 \mu \mathrm{g} 1^{-1}$ in GFST. The chlorophyll maximum was in spring (Figures 3 and 5). The mechanisms that trigger the spring bloom of phytoplankton in such areas have been demonstrated by Sverdrup (1953). Stratification of the upper layers together with a seasonal increase of irradiance are key processes for the initiation of the bloom, as well as the grazing pressure in response to the increased phytoplankton biomass (Siegel et al., 2002). The GeP\&CO cruises in April captured the phytoplankton spring bloom, which was marked by a fucoxanthin maximum. Oppositely, in summer and autumn (July and October, respectively), there was a maximum in the percentage of d-Chl $a$ and in zeaxanthin.

In ARCH (Fig. 11), loss of heat to the atmosphere and consecutive cooling of the ocean surface mixed layer during the austral winter is known to entrain nutrients from depth into the photic layer, resulting in a chlorophyll maximum (Dandonneau and Gohin, 1984; Longhurst, 1998). This maximum was detected in August of 2000, 2001 and 2002 and exceeded $0.20 \mu \mathrm{g} \mathrm{l}^{-1}$ on average in the GeP\&CO data. It corresponded to the minimum of \%dChla and to a weak fucoxanthin maximum. Farther south, the GeP\&CO data were strongly influenced by coastal processes near New Zealand, which were responsible for high chlorophyll concentration, mostly contributed by microplankton, with a maximum in spring (Chang et al., 2003). In this province, which extends from $23{ }^{\circ} \mathrm{S}$ to $35^{\circ} \mathrm{S}, \% \mathrm{dChla}$ and $\%$ Pico were relatively high all year long. Nutrient levels remained low throughout the year, probably 
because the upward entrainment flux was slow and nutrients were immediately taken up by new production.

The other provinces are located between the tropics, and seasonal cycles are weaker. CARB is known as an area where dinitrogen fixation contributes significantly to new production (Coles et al., 2004). A chlorophyll maximum in winter has often been reported to occur either at the Bermuda time series station located to the northeast (Menzel and Ryther, 1961; Johnson and Howd, 2000) or in the neighbouring Gulf of Mexico (Müller-Karger et al., 1991; Dandonneau et al., 2004). The GeP\&CO data did not suggest any clear seasonal cycle in this province (Fig. 6), except for sea-surface temperature $\left(27^{\circ} \mathrm{C}\right.$ in February and April, 28 ${ }^{\circ} \mathrm{C}$ in August and November). Isolated events, such as the maximum of fucoxanthin in April 2000 in CARB (Fig. 6), dominated the variability here rather than a possible seasonal cycle. Similarly, the high value of \%dChla from May 2000 to February 2001 in PNEC (Fig. 7) dominated the three year long GeP\&CO record in this province. A longer time series would be needed to isolate the seasonal variability from noise in CARB and PNEC. By contrast, the permanently oligotrophic SPSG (Fig. 10) had higher average chlorophyll concentrations in May $\left(0.077 \mu \mathrm{g}^{-1}\right)$ and August $\left(0.088 \mu \mathrm{g}^{-1}\right)$ than in November $\left(0.047 \mu \mathrm{g} 1^{-1}\right)$ or February $\left(0.054 \mu \mathrm{g} \mathrm{l}^{-1}\right)$ and thus exhibited a small but clear seasonal cycle, which had already been pointed out by Longhurst (1998) and by Dandonneau et al. (2004). A similar pattern has been described for the North Atlantic subtropical gyre by Neuer et al. (2002) and Bahamon et al. (2003). Furthermore, the contribution of d-Chl $a$ to Tchla, as well as the zeaxanthin concentration, culminated in the austral winter, indicating that Prochlorococcus sp. and picoplankton had contributed to this maximum. It is, however, unlikely that nutrients are entrained upwards into the photic layer in this very oligotrophic province where the water column is permanently stratified and the pycnocline and nutricline are always deep. Rather, the slight winter chlorophyll maximum observed by GeP\&CO might, at least partly, be a response of the photosystem antenna to less intense irradiance (Cloern et al., 1995).

PEQD is known as the site of the interannual El Niño anomaly that dominates its possible seasonal variability (Murray et al., 1994). However, no such event occurred during the GeP\&CO sampling. It is also known for its permanent upwelling along the equator, which intensifies each year from July to December when trade winds reinforce seasonally (Wyrtki and Kilonsky, 1984). The variations of sea surface temperature shown on Fig. 9 respond to this latter pattern. Nitrate available for primary production varied between 4 and $8 \mu$ mole $1^{-1}$ 
but was not well phased with this upwelling reinforcing and seasonal cooling. This discrepancy in the nitrate-temperature relationship probably results from the removal of nitrate by the phytoplankton. In spite of such important relative variations of nitrate, Tchla remained remarkably constant throughout the 1999-2002 observed period, as well as \%dChl a, zeaxanthin and the proportions of pico-, nano- and microplankton (Fig. 9). This evenness of the equatorial Pacific ecosystem has already been emphasised by Longhurst (1998) and probably results from iron limitation that persists throughout the year, giving this province the HNLC character discussed above (Fig. 12).

\subsection{Oceanic provinces}

The ocean's ability to support the growth of the phytoplankton is basically the same in all areas: there are nutrients in abundance at depth and light at the surface. Biogeochemical variability arises from the history and properties of the surface mixed layer. Areas with a permanently nutrient-exhausted surface layer differ strongly from those that are supplied with nutrients, either seasonally at high latitudes or continuously such as in upwellings. CARB, PNEC, SPSG and ARCH on the one side and NADR, GFST and PEQD on the other side correspond to this division between nutrient-depleted and nutrient supplied areas. In addition, SPSG and PEQD differ from the other provinces, because they receive no, or very little, atmospheric iron. Given these limiting conditions for phytoplankton growth and their spatial distribution, the framework offered by Longhurst (1998), who divided the ocean into provinces, is convenient for this study. Even CARB and ARCH differed markedly, the latter being located at higher latitudes and subject to a seasonal cycle that cannot be seen in CARB (Figs. 6 and 11). It was less easy to differentiate between NADR and GFST. These two provinces exhibited chlorophyll and fucoxanthin maxima in spring and still contained abundant fucoxanthin in July, and the nutrient maximum was in spring and winter (Figures 3 and 5). Based on objective criteria for a given data set, Hooker et al. (2000) identified NADRtype water masses as far south as $32^{\circ} \mathrm{N}$. The most obvious differences between the two provinces can be seen here in the coccolithophore population data (see 4.4) and in the variations in size of the phytoplankton (derived from its photosynthetic pigments): nanoplankton ( 2 to $20 \mu \mathrm{m}$ in size) accounted for about $40 \%$ of the total phytoplankton biomass at all seasons in NADR, while it accounted for only $25 \%$ in GFST. This lower relative contribution of nanoplankton in GFST was balanced by relatively higher microplankton levels in winter and spring and higher picoplankton levels in summer and autumn. Longhurst (1998) emphasised the generation of eddies in GFST and the 
consequences of these eddies on the ecosystem. However, the seasonal cycles that he worked out for these two provinces do not differ markedly. The differences between them cannot be drawn from the GeP\&CO quarterly data alone, and they might result from a lag in the phase of the spring bloom in the eastern or western North Atlantic. They may also be due to the route taken by the ship (Fig. 1), since GeP\&CO sampled the very south of NADR and the north of GFST. Generally, with only a few minor changes (for the shifted boundaries of PEQD, see the results section), the oceanic provinces defined by Longhurst (1998) provided a pertinent and useful framework for analysing the GeP\&CO data.

\subsection{Coccolithophorids}

Changes in species and diversity of coccolithophore populations observed during the GeP\&CO transects in the North Atlantic (Fig. 4) and Pacific (Fig. 8) are in agreement with the division into biogeographical provinces defined by Longhurst (1998) according to differences in physical environment and algal dynamics. The relative abundance of coccolithophore species across the NADR and GFST provinces (April 2000) on the one hand and across the PNEC, PEQD and SPSG provinces (February 2001) on the other hand revealed two markedly different situations (Fig. 13). The North Atlantic record during the boreal spring in 2000 showed two sub-domains within NADR: an eastern one between 10 and $20^{\circ} \mathrm{W}$ with Gephyrocapsa muellerae as the dominant species and a western one dominated by a heavily calcified morphotype of $\underline{\text { E.huxleyi }}$ ("closed" $\underline{\text { E. huxleyi }}$ ). These two subdomains also differed by their latitude, the former corresponding to a temperate regime at about $45^{\circ} \mathrm{N}$, while the latter was closer to the subtropical gyre. The GFST province had higher species diversity, which probably resulted from the route of the ship being close to a highly dynamical frontal area with meanders and subsequent intrusions of subpolar- and subtropical-thriving species. This distribution of coccolithophore species generally corresponded to the results published by Okada and McIntyre (1979). Our record of changes in coccolithophore species in the equatorial and South Pacific Central gyre (Fig. 13, February 2000) can be seen as a dataset complementary to the unique record published by Okada and Honjo (1973) for the North and equatorial Pacific: the succession of coccolithophore groups of species identified along the GeP\&CO route was symmetrical to the one observed in the northern hemisphere, with $\underline{G}$. oceanica, E. huxleyi and Umbellosphaera irregularis dominating the populations in PNEC, PEQD and SPSG, respectively. This pattern of distribution of coccolithophore species therefore seems to be valid for the whole tropical and subtropical Pacific. 
The coccolithophorids often dominate the Haptophytes in the open ocean. The microscopic enumerations of coccolithophore cell abundance and measurements of $19^{\prime} \mathrm{HF}$ concentration, a marker pigment for Haptophytes (=Prymnesiophytes), offers an opportunity to evaluate how tightly the concentration of this diagnostic pigment is correlated to the abundance of this group. A crude global comparison (Figs. 4 and 8) showed poor agreement between the two variables. The agreement improved in provinces characterized by high coccolithophore standing stocks such as in GFST (Fig. 4) where peak concentrations of 19'HF up to $0.12 \mu \mathrm{g} \mathrm{l}^{-1}$ in April 2000 were associated with the highest coccolithophore standing stocks (around 130 cells ml $\mathrm{m}^{-1}$ ). The general disagreement between the two variables was possibly caused by changes in pigment ratios in different coccolithophorid species or in other groups containing 19'HF (Jeffrey and Wright, 1994); the seasonal evolution of the nearly monospecific (G. oceanica) coccolithophore populations in the PNEC province (Fig. 8) was indeed a good match with the evolution of 19'HF concentrations, suggesting that species diversity has to be considered in this respect. 19' $\mathrm{HF}$ content might be more tightly related to the total volume of coccolithophore cells than to cell numbers. The coccolithophore volume in one $\mathrm{ml}$ varies between 5 and $28 \mu \mathrm{m}^{3}$. As a test we plotted (Fig. 14a) the distribution of coccolithophore standing stocks, the calculated biovolumes based on our microscopic observations and $19^{\prime} \mathrm{HF}$ across the Pacific region during February 2000. Biovolumes showed large amplitude changes (larger than cell numbers) across this oceanic domain, especially in the southern part of PEQD. In this province, large-amplitude changes were only imperfectly traced by changes in $19^{\prime} \mathrm{HF}$, while the large scale trends of this diagnostic pigment fit relatively well with the trends in both biovolumes and cell numbers in the nearby SPSG and PNEC provinces. The same tropical-Pacific-wide survey indicated that the largest discrepancy between both sets of data occurred in the mesotrophic PEQD province, where peak values of 19 'HF concentrations were barely associated with high coccolithophore biovolumes or standing stocks (Fig. 14b). This suggested that the overall imperfect agreement between pigment and cells concentrations (or biovolumes) of coccolithophores could also be a consequence of organic-scale producing Haptophytes such as Phaeocystis or others, which are known to also contain 19'HF (Belviso et al., 2001). They are successful in a wide range of coastal or open ocean eutrophic domains and might well be involved in the peak 19'HF concentrations recorded in surface waters of the PEQD province (Fig. 14b). A relatively great abundance and diversity of prymnesiophytes in the picoplanktonic community of the Pacific equatorial upwelling were inferred from 18S rDNA sequences (Moon-van der Staay et al., 
$2000)$ at $150^{\circ} \mathrm{W}$ (little west from the PEQD province described here). In this case, $19^{\prime} \mathrm{HF}$ was also the main carotenoid.

\subsection{Diatoms}

Diatoms are the most efficient among the phytoplankton in exporting carbon to depth, and fucoxanthin is often considered as the diagnostic pigment for this group of algae (Blain et al., 1999), even though some other groups of algae may contain it, such as the Chrysophyceae, the Prymnesiophyceae, the Raphidophyceae (Jeffrey et al., 1997) or the Bolidophyceae (Guillou et al., 1999). As expected, fucoxanthin was abundant during the spring bloom in NADR and GFST (Figures 3 and 5) and remained present in significant amounts in these provinces during the rest of the year. In contrast, it was practically not found in the very oligotrophic SPSG (Fig. 10). Between these extremes, it occurred in relatively large amounts sporadically in PNEC (Figure 7) and was found in abundance in CARB in May 1999 (Fig. 6). Such brief peaks of fucoxanthin support the hypothesis that new production in tropical areas might result from the growth of diatoms (Goldman, 1993). In ARCH, fucoxanthin was present during each austral winter $\left(0.026 \mu \mathrm{g}^{-1}, 0.015 \mu \mathrm{g}^{-1}\right.$ and $0.038 \mu \mathrm{g} \mathrm{l^{-1 }}$ in August of 2000, 2001 and 2002), when Tchla was at a maximum (Fig. 11). This confirmed that nitrate is entrained into the surface mixed layer in winter (Dandonneau and Gohin, 1984) and that the resulting new production is at least partly due to diatoms. According to Chavez (1989), who found that the equatorial Pacific was dominated by small cells in all circumstances, high fucoxanthin concentrations did not occur in PEQD in spite of high nitrate and silicate contents: measurements in this province indeed indicated very low concentrations averaging only $0.011 \mu \mathrm{g} \mathrm{l}^{-1}$ (Fig. 9), bringing additional evidence that phytoplankton growth is strongly limited in this HNLC area. Blooms of diatoms (Archer et al., 1997) or highgrowth-rate events (Bender and McPhaden, 1990) are thus certainly the exception in this province.

\subsection{Picoplankton}

The picoplankton is composed of tiny cells (less than 2 microns in diameter) that are well adapted to assimilate nutrients at low concentrations and that sink very slowly. Their contribution to export production is thus small and their photosynthesis, respiration and source of food for grazing contribute to the microbial loop (Azam et al., 1983). The GeP\&CO database contains two kinds of measurements for estimating the biomass of picoplankton: 
direct cell counts by flow cytometry or indirect estimates via diagnostic pigments: zeaxanthin for Cyanobacteria, d-Chl $b$ for Prochlorophytes and $\mathrm{Chl} b$ for Prochlorococcus and small chlorophytes (Chlorophyceae, Prasinophyceae). As mentioned in the methods section, flow cytometry GeP\&CO counts failed to detect Prochlorococcus sp. in well lighted surface tropical waters. Given this gap, picoplankton biovolume computed as the sum of Synechococcus ( $1 \mu \mathrm{m}$ in diameter) and picoeucaryotes $(1.7 \mu \mathrm{m}$ in diameter $)$ and biomass estimated with the diagnostic pigments were not tightly correlated $\left(r^{2}=0.32\right)$. The abundance of Synechococcus and of picoeucaryotes generally varied as for Tchla. There were some regional specificities: Synechococcus was most abundant in PNEC and in ARCH (Figs. 7 and 11), where their average concentration often exceeded 50000 cells ml$^{-1}$ (i. e. more than in the productive NADR and GFST, as shown in Figs. 2 and 4). Picoeucaryotes were more abundant relatively to Tchla in PEQD (Fig. 9) than in other provinces and exhibited high concentrations occasionally, such as in May and November 2001 in PNEC (Fig. 7), in May 2001 in SPSG (Fig. 10), or in December 1999, August 2001, or May 2001 in ARCH (Fig. 11).

It is generally considered that Prochorococcus sp. is characteristic of warm waters and practically disappears from temperate waters in winter, when temperature decreases below $13^{\circ} \mathrm{C}$ (Partensky et al., 1999). Our measurements of significant amounts of d-chl $a$ in winter in the North Atlantic (Figs 3 and 5) did not confirm this assumption. Prochlorococcus sp. was detected by flow cytometry in NADR at temperatures ranging between 11 and $15^{\circ} \mathrm{C}$ each winter and spring, when its fluorescence was not depressed by high irradiance and its abundance was positively correlated to sea surface temperature. However, while average sea surface temperature in April was approximately equal to that in January $\left(13.54^{\circ} \mathrm{C}\right.$ and $13.52^{\circ} \mathrm{C}$ respectively in $2001,14.36$ and 14.03 in 2002; no data in 2000), Prochlorococcus sp. was less abundant in April (797 cells ml ${ }^{-1}$ vs 6590 in 2000, 1250 vs 6240 in 2001 and 2790 vs 18400 in 2002). Thus, it seems that Prochlorococcus sp. tends to vanish during February and March when the temperature reaches its minimum and that it does not respond to the temperature increase in spring, contrary to the well adapted diatoms. In the tropical provinces, d-Chl $a$ contributed much more to Tchla. This contribution was smaller in regions where nutrients are not totally exhausted (22\% in PNEC and PEQD) than in oligotrophic ones (32\% in ARCH, $35 \%$ in CARB and $39 \%$ in SPSG). This confirmed that Prochlorococcus $s p$. is better adapted to oligotrophic environments than the other species. 
High zeaxanthin to Chl $a$ ratios generally characterize populations which are adapted to high irradiance and a low nutrients regime (Demmig-Adams et al., 2000). PNEC is the province where we found zeaxanthin to be most abundant $\left(0.089 \mu \mathrm{g}^{-1}\right)$. In ARCH, it seemed to vary in phase with Tchla and fucoxanthin, as if zeaxanthin-containing algae benefited from the supply of nutrients that occurs in winter; variations, however, were very small, and average concentration was $0.054 \mu \mathrm{g}^{-1}$. In CARB and PEQD, zeaxanthin did not vary much, and its average was $0.056 \mu \mathrm{g}^{-1}$ and $0.062 \mu \mathrm{g} \mathrm{l^{-1 }}$, respectively. SPSG, the most oligotrophic province and a well lighted one, had very low phytoplankton biomass, and zeaxanthin concentration was only $0.039 \mu \mathrm{g}^{-1}$. In spite of its higher biomass, NADR had even less zeaxanthin, averaging only $0.023 \mu \mathrm{g}^{-1}$. GFST exhibited ample variations of zeaxanthin, from nearly null concentration in winter and spring to about $0.060 \mu \mathrm{g}^{-1}$ when fucoxanthin was at a minimum. Thus, zeaxanthin was present only when irradiance was high (in agreement with its photoprotectant role and also because community structure is composed of cells rich in zeaxanthin in summer), and in such conditions its abundance is positively related to phytoplankton biomass.

\section{Conclusion}

GeP\&CO is one of the few series of cruises that have sampled the ocean on long tracks on a seasonal basis. The biannual Atlantic Meridional Transects from England to the southern Atlantic (Barlow et al., 2002) are another such series, and measurements are still being pursued. They include oceanographic stations and focus on the validation of products derived from satellite-detected sea color. HPLC pigments have also been sampled monthly through the North Pacific along the commercial ship track from Canada to Japan (Obayashi et al., 2001). The GeP\&CO cruises were scheduled for three years and ended in 2002. Their frequency was higher than that of the Atlantic Meridional Transect, with cruises every 3 months, and the duration of the experiment is longer than that of the Japan-to-Canada transect. The range of oceanic conditions covered was different, with GeP\&CO cruises sailing mostly in oceanic waters, with only a small portion of their track in coastal waters (along the east coast of North America). The GeP\&CO and North Pacific cruises had to adapt to the conditions of a commercial ship, sampling being limited to the sea surface as a result and to a variety of parameters that could be handled by a single operator onboard. We did our best in 
the GeP\&CO so that all parameters were measured on all cruises by the same protocols, in order to build a coherent database with as few gaps as possible. Finally, it was possible to organize the GeP\&CO programme with no major problems occurring, and the resulting database covered every three months a very large section across the world ocean through a variety of oceanic provinces. We have demonstrated here that the GeP\&CO data are generally in agreement with current knowledge of the regional and seasonal variability of the ocean. Our results have been organized according to Longhurst's (1998) division of the ocean into provinces. Generally, the description and timing of the annual bloom and succession of phytoplankton made by this author has been confirmed by the GeP\&CO data. The GeP\&CO data also included many parameters that were not routinely sampled in the past, such as light absorption spectra by phytoplankton and colored dissolved organic matter, surface seawater reflectances or accessory photosynthetic pigments measured by HPLC or spectrofluorometry. We are also working on excitation-emission fluorescence spectra that contain information on the fluorescence of phycoerythrin, and we are processing these spectra to derive phycoerythrin concentration from all GeP\&CO observations.

The detailed GeP\&CO pigment inventories reflect the phytoplankton assemblages. They have been used to evidence relationships between satellite-detected sea-color anomalies and dominant phytoplankton groups (Alvain et al., 2005). Knowledge of dominant phytoplankton groups indeed makes it possible to better understand how chemical elements vary and how they are advected or exported in the ocean. Deriving phytoplankton groups from pigment inventories is not a simple matter and requires a profound knowledge of the ecology of these groups and of pigment ratios inside them. For instance, the common assumption that 19 'hexanoyloxyfucoxanthin is a proxy for coccolithophores has been shown here to be questionable. Nevertheless, the information that quantitative pigment inventories contain makes it possible to describe the phytoplankton populations with much more insight than allowed by only bulk chlorophyll a determinations or scarce identifications of species. Finally, with the addition of nutrient and carbonate data, GeP\&CO has built up a convenient and homogeneous dataset that should prove very useful for validating global biogeochemical models, which now include more and more functional types of plankton.

(The GeP\&CO data can be obtained from http://www.obs-vlfr.fr/proof/). 


\section{Acknowledgements}

We are especially grateful to Philippe Gérard, Joël Orempuller, Rémi Chuchla, Denis

Diverrés and François Baurand who ensured the GeP\&CO sampling and measurements on M. S. Contship London. We are also grateful to the successive captains, officers and crews of Contship London for kindly helping to solve all difficulties during the cruises and to the owner and manager of the ship, respectively MS "Alexandra Rickmers" Schiffsbeteiligungsgesellschaft $\mathrm{mbH} \& \mathrm{Co}$ and Marine Consulting \& Contracting Gmbh in Hamburg. During the first operational years of GeP\&CO,Yves Montel and Jean Blanchot were respectively at the Station Marine d'Arcachon and at the Station Biologique de Roscoff. 


\section{References}

Alvain, S., Moulin, C., Dandonneau, Y., Breon, F. M., 2005. Remote sensing of phytoplankton groups in case I waters from global SeaWiFS imagery. Deep Sea Research Part I 52, 1989-2004.

Archer, D., Aiken, J., Balch, W., Barber, D., Dunne, J., Flament, P., Gardner, W., Garside, C., Goyet, C., Johnson, E., 1997. A meeting place of great ocean currents: shipboard observations of a convergent front at $2^{\circ} \mathrm{N}$ in the Pacific. Deep Sea Research Part II 44, 1827-1849.

Aumont, O., Maier-Reimer, E., Blain, S., Monfray, P., 2003. An ecosystem model of the global ocean including Fe, Si, P colimitations. Global Biogeochemical Cycles 17, 1060, doi:10.1029/2001GB001745.

Azam, F., Fenchel, T., Field, J.G., Gray, J.S., Meyer-Reil, L.A., F. Thingstad, F., 1983. The ecological role of water-column microbes in the sea. Marine Ecology Progress Series 10, 257-263.

Bahamón, N., Velasquez, Z., Cruzado, A., 2003. Chlorophyll $a$ and nitrogen flux in the tropical North Atlantic Ocean . Deep-Sea Research Part I 50, 1189-1203.

Barlow, R.G., Aiken J., Holligan, P.M., Cummings, D.G., Maritorena, S., Hooker, S., 2002. Phytoplankton pigment and absorption characteristics along meridional transects in the Atlantic Ocean. Deep-Sea Research I 47, 637-660.

Beaufort, L., Heussner, S., 2001. Seasonal dynamics of calcareous nannoplankton on a West European continental margin: the Bay of Biscay. Marine Micropaleontology 43, 27-55.

Belviso, S., Claustre, H., Marty, J.-C., 2001. Evaluation of the utility of chemotaxonomic pigments as a surrogate for particulate DMSP. Limnology and Oceanography 46, 989-995. 
Bender, M.L., McPhaden, M.J., 1990. Anomalous nutrient distribution in the equatorial Pacific in April 1988 : evidence for rapid biological uptake. Deep-Sea Research 37, 10751084.

Bisset, W.P., Walsh, J.J., Dieterle, D.A., Garder, K.L., 1999. Carbon cycling in the upper waters of the Sargasso sea : I. Numerical simulation of differential carbon and nitrogen fluxes. Deep-Sea Research I 46, 205-269.

Blain, S., Tréguer, P., Rodier, M., 1999. Stocks and fluxes of biogenic silica in the western oligotrophic equatorial Pacific. Journal of Geophysical Research 104, 3357-3367.

Blanchot, J., Rodier, M., 1996. Picophytoplankton abundance and biomass in the western tropical Pacific Ocean during the 1992 El Niño year : results from flow cytometry. DeepSea Research I 43, 877-895.

Boyd, P., Newton, P. (1995). Evidence of the potential influence of planktonic community structure on the interannual variability of particulate carbon flux. Deep-Sea Research I, 42, 619-639.

Bricaud, A., Claustre, H., Ras, J., Oubelkheir, K., 2004. Natural variability of phytoplanktonic absorption in oceanic waters: Influence of the size structure of algal populations. Journal of Geophysical Research 109, doi:10.1029/2004JC002419.

Chang, F.H., Zeldis, J., Gall, M., Hall, J., 2003. Seasonal and spatial variation of phytoplankton assemblages, biomass and cell size from spring to summer across the northeastern New Zealand continental shelf. Journal of Plankton Research 25, 737-758.

Chavez, F., 1989. Size distribution of phytoplankton in the central and eastern tropical Pacific. Global Biogeochemical Cycles 3, 27-35.

Cloern, J.E., Grenz, C., Vidergar-Lucas, L., 1995. An empirical model of the phytoplankton chlorophyll : carbon ratio - the conversion factor between productivity and growth rate. Limnology and Oceanography 40, 1313-1321. 
Coles, V.J., Wilson, C., Hood, R.R., 2004. Remote sensing of new production fuelled by nitrogen fixation. Geophysical Research Letters 31, L06301, doi:10.1029/2003GL019018.

Dandonneau, Y., Deschamps, P.-Y., Nicolas, J.-M., Loisel, H., Blanchot, J., Montel, Y., Thieuleux, F., Bécu, G., 2004. Seasonal and interannual variability of ocean color and composition of phytoplankton communities in the North Atlantic, Equatorial Pacific and South Pacific. Deep-Sea Research part II 51, 303-318.

Dandonneau, Y., Eldin, G., 1987. Southwestward extent of chlorophyll-enriched waters from the Peruvian and equatorial upwellings between Tahiti and Panama. Marine Ecology Progress Series 38, 283-294.

Dandonneau, Y., 1995. Sea-surface partial pressure of carbon dioxide in the eastern equatorial Pacific (August 1991 to October 1992) : a multivariate analysis of physical and biological factors. Deep-Sea Research II 42, 349-364.

Dandonneau, Y., Gohin, F., 1984. Meridional and seasonal variations of the sea surface chlorophyll concentration in the southwestern tropical Pacific ( 14 to $32^{\circ} \mathrm{S}, 160$ to $\left.175^{\circ} \mathrm{E}\right)$. Deep-Sea Research 31, 1377-1393.

Demmig-Adams, B., Adams III, W.W., 2000. Harvesting sunlight safely. Nature 403, 371374.

Dugdale, R.C., Wilkerson, F.P., 1991. Low specific nitrate uptake rate : A common feature of high-nutrient, low-chlorophyll marine ecosystems. Limnology and Oceanography 36, $1678-1688$.

Suzuki, R., Fujita, Y., 1986. Chlorophyll decomposition in Skeletonema costatum: a problem in chlorophyll determination of water samples. Marine Ecology Progress Series 28, 81-85.

Giraudeau, J., Bailey, G.W., 1995. Spatial dynamics of coccolithophore communities during an upwelling event in the Southern Benguela system. Continental Shelf Research 15, 1825 1852. 
Goericke, R., Repeta, D.J., 1993. Chlorophylls a and b and divinyl chlorophylls a and b in the open subtropical North Atlantic Ocean. Marine Ecology Progress Series 101, 307-313.

Goldman, J., 1993. Potential role of large oceanic diatoms in new primary production. DeepSea Research I 40, 159-168.

Gordon, M.R., Coale, K.H., Johnson, K.S., 1997. Iron distributions in the equatorial Pacific : implications for new production. Limnology and Oceanography 42, 419-431.

Guillou, L., Moon-van der Stay, S.-Y., Claustre, H., Partensky, F., Vaulot, D. 1999. Diversity and abundance of Bolidophyceae (Heterokonta) in two oceanic regions. Applied and Environmental Microbiology 65, 4528-4536.

Hooker, S.B., Rees, N.W., Aiken, J., 2000. An objective methodology for identifying oceanic provinces. Progress in Oceanography 45, 313-338.

Jeffrey, S.W., Hallegraeff, G.M., 1987. Chlorophyllase distribution in ten classes of phytoplankton: a problem for chlorophyll analysis. Marine Ecology Progress Series 35, 293-304.

Jeffrey, S. W., Mantoura, R.F.C. Wright S.W. 1997. Phytoplankton pigments in Oceanography. United Nations Educational, Scientific and Cultural Organization, Paris, $661 \mathrm{p}$.

Jeffrey, S.W., Wright, S.W., 1994. Photosynthetics pigments in the Haptophyta. In : Green, J.C., Leadbeater, B.S.C. (Eds.), The Haptophyte Algae. Clarendon Press, 111-132.

Johnson, Z., Howd, P., 2000. Marine photosynthetic performance forcing and periodicity for the Bermuda Atlantic Time Series, 1989-1995. Deep-Sea Research I 47, 1485-1512.

Karl, D., Letellier, R., Tupas, L., Dore, J., Christians, J., Hebel, D., 1997. The role of nitrogen fixation in biogeochemical cycling in the subtropical North Pacific Ocean. Nature 388, 533-538. 
Landry, M.R., Barber, R.T., Bidigare, R.R., Chai, F., Coale, K.H., Dam, H.G., Lewis, M.R., Lindley, S.T., McCarthy, J.J., Roman, M.R., Stoecker, D.K., Verity, P.G., White, J.R., 1997. Iron and grazing constraints on primary production in the central equatorial Pacific : an EqPac synthesis. Limnology and Oceanography 42, 405-418.

Le Borgne, R., Champalbert, G., Gaudy, R., 2003. Mesozooplankton biomass and composition in the equatorial Pacific along $180^{\circ}$. Journal of Geophysical Research 108, doi:10.1029/2000JC000745

Le Quéré, C.S., Harrison, P., Prentice, I.C., Buitenhuis, E.T., Aumont, O., Bopp, L., Claustre, H., Cotrim da Cunha, L., Geider, R., Giraud, X., Klaas, C., Kohfeld, K.E., Legendre, L., M. Manizza, M., Platt, T., Rivkin, R.B., Sathyendranath, S., Uitz, J., Watson, A.J., WolfGladrow, D., 2005. Ecosystem dynamics based on plankton functional types for global ocean biogeochemistry models. Global Change Biology 11: 2016-2040.

Letelier, R. M., Bidigare, R. R., Hebel, D. V., Ondrusek, M., Winn, C. D., Karl, D. M., 1993. Temporal variability of phytoplankton community structure based on pigments analysis. Limnology and Oceanography 38: 1420-1437.

Lochte, K., Ducklow, H.W., Fasham, M.J.R., Stienens, C., 1993. Plankton succession and carbon cycling at $47^{\circ} \mathrm{N} 20^{\circ} \mathrm{W}$ during the JGOFS North Atlantic Bloom Experiment. DeepSea Research II 40, 91-114.

Longhurst, A., 1998. Ecological geography of the sea. Academic Press, London, 398 p.

Mackey, M.D., Mackey, D.J., Higgins, H.W., Wright, S.W., 1996. CHEMTAX - a program for estimating class abundances from chemical markers : application to HPLC measurements of phytoplankton. Marine Ecology Progress Series 144, 265-283.

Martin, J. H., 1992. Iron as a limiting factor in oceanic productivity. Falkowski, Paul G. and Woodhead, Avril D. 123-137. New York, Plenum Press.

Menzel, D.W., Ryther, J.H., 1961. Annual variations in primary production of the Sargasso 
sea off Bermuda. Deep-Sea Research 7, 282-288.

Moon-van der Stay, S.-Y., Van der Stay, G. W. M., Guillou, L., Vaulot, D., Claustre, H., Medlin, L. K., 2000. Abundance and diversity of prymnesiophytes in the picoplankton community from the equatorial Pacific Ocean inferred from 18S rDNA sequences. Limnology and Oceanography 45, 98-109.

Morel, A., 1991. Light and marine photosynthesis : a spectral model with geochemical and climatological implications. Progress in Oceanography 26, 263-306.

Müller-Karger, F.E., Walsh, J.J., Evans, R.H., Meyers, M.B., 1991. On the seasonal phytoplankton concentration and sea surface temperature cycles of the Gulf of Mexico as determined by satellites. Journal of Geophysical Research 96, 12645-12665.

Murray, J.W., Barber, R.T., Roman, M.R., Bacon, M.P., Feely, R.A., 1994. Physical and biological controls on carbon cycling in the equatorial Pacific. Science 266, 58-65.

Neuer, S., Davenport, R., Freudenthal, T., Wefer, G., Llinas, O., Rueda, M.-J., Steinberg, D.K., Karl, D.M., 2002. Differences in the biological carbon pump at three subtropical ocean sites. Geophysical Research Letters 29, 1885, doi:10.1029/2002GL015393.

Neveux, J., 1988. Extraction of chlorophylls from marine phytoplankton. Verhandlungen. Internationale Vereinigung Für Theoretische und Angewandte Limnologie 23, 928-932.

Neveux, J., Lantoine, F., 1993. Spectrofluorometric assay of chlorophylls and phaeopigments using the least squares approximation technique. Deep-Sea Research I 40, 1747-1765.

Obayashi, Y., Tanoue, E., Suzuki, K., Handa, N., Nojiri, Y., Wong, C. S., 2001. Spatial and temporal variabilities of phytoplankton community structure in the northern North Pacific as determined by phytoplankton pigments. Deep-Sea Research I, 40, 439-469.

Okada, H., Honjo, S., 1973. The distribution of oceanic coccolithophorids in the Pacific. Deep-Sea Research 20, 355-374. 
Okada, H., McIntyre, A., 1979. Seasonal distribution of modern coccolithophores in the western North Atlantic Ocean. Marine Biology 54, 319-328.

Partensky, F., Hess, W. R., Vaulot, D., 1999. Prochlorococcus, a marine photosynthetic Procaryote of global significance. Microbiology and Molecular Biology Reviews 63, 106127.

Platt, T., Sathyendranath, S., 1991. Biological production models as elements of coupled, atmosphere-ocean models for climate research. Journal of Geophysical Research 96, 25852592.

Robertson, J.E., Robinson, C., Turner, D.R., Holligan, P., Watson, A.J., Boyd, P., Fernandez, E., Finch, M., 1994. The impact of a coccolithophore bloom on oceanic carbon uptake in the northeast Atlantic during summer 1991. Deep-Sea Research I 41, 297-314.

Romero, O. E., Hebbeln, D., Wefer, G., 2001. Temporal and spatial variability in export production in the SE Pacific Ocean : evidence from siliceous plankton fluxes and surface sediment assemblages. Deep-Sea Research I 48, 2673-2697.

Siegel, D.A., Doney, S.C., Yoder, J.A., 2002. The North Atlantic spring phytoplankton bloom and Sverdrup's critical depth hypothesis. Science 296, 730-733.

Six, K.D., Maier-Reimer, E., 1996. Effects of plankton dynamics on seasonal carbon fluxes in an ocean general circulation model. Global Biogeochemical Cycles 10, 559-583.

Sosik, H.M., 1999. Storage of marine particulate samples for light-absorption measurements. Limnology and Oceanography 44, 1139-1141.

Strickland, J.D.H., Parsons, T., 1972. A practical handbook of seawater analysis. Fisheries Research Board of Canada Bulletin 167, 1-310.

Subramaniam, A., Brown, C.W., Hood, R.R., Carpenter, E.J., Capone, D.G., 2002. Detecting Trichodesmium blooms in SeaWiFS imagery. Deep-Sea Research II 49, 107-121. 
Sverdrup, H.U., 1953. On conditions for the vernal blooming of phytoplankton. Journal du Conseil 18, 287-295.

Thomas, W.H., 1979. Anomalous nutrient-chlorophyll interrelationships in the offshore eastern tropical Pacific Ocean. Journal of Marine Research 37, 327-335.

Tyrrell, T., Holligan, P. M., Mobley, C. D., 1999. Optical impact of oceanic coccolithophore blooms. Journal of Geophysical Research 104 : 3223-324.

Vaulot, D., 1989. CYTOPC : processing software for flow cytometric data. Signal Noise 2, 8.

Vidussi, F., Claustre, H., Manca, B.B., Luchette, A., Marty, J.-C., 2001. Phytoplankton pigment distribution in relation to upper thermocline circulation in the eastern Mediterranean Sea during winter. Journal of Geophysical Research 106, 19939-19956.

Williams, R., Claustre, H., 1991. Photosynthetic pigments as biomarkers of phytoplankton populations and processes involved in the transformation of particulate organic matter at the Biotrans site $\left(47^{\circ} \mathrm{N}, 20^{\circ} \mathrm{W}\right)$. Deep-Sea Research 38, 347-355.

Wyrtki, K., Kilonsky, B., 1984. Mean water and current structure during the Hawaii-to-Tahiti Shuttle Experiment. Journal of Physical Oceanography 14, 242-254. 


\section{Tables}

Table 1.- Dates of GeP\&CO cruises (year-month-day).

\begin{tabular}{|c|c|c|c|c|c|c|}
\hline Cruise & $\begin{array}{l}\text { Le Havre } \\
\text { (departure) }\end{array}$ & New York & Panama & Tahiti & Auckland & $\begin{array}{c}\text { Nouméa } \\
\text { (arrival) }\end{array}$ \\
\hline GeP\&CO_A & $99-11-01$ & $99-11-07$ & $99-11-15$ & $99-11-24$ & $99-12-01$ & $99-12-05$ \\
\hline GeP\&CO_B & $00-01-25$ & $00-02-02$ & $00-02-08$ & $00-02-18$ & $00-02-25$ & $00-02-28$ \\
\hline GeP\&CO_C & 00-04-20 & 00-04-28 & $00-05-05$ & $00-05-15$ & $00-05-22$ & $00-05-25$ \\
\hline GeP\&CO_D & $00-07-23$ & $00-07-31$ & $00-08-07$ & $00-08-18$ & $00-08-23$ & $00-08-25$ \\
\hline GeP\&CO_E & $00-10-16$ & $00-10-23$ & $00-10-31$ & $00-11-10$ & $00-11-17$ & $00-11-20$ \\
\hline GeP\&CO_F & 01-01-15 & $01-01-23$ & $01-01-29$ & 01-02-08 & $01-02-14$ & $01-02-16$ \\
\hline GeP\&CO_G & 01-04-10 & 01-04-17 & $01-04-25$ & 01-05-05 & 01-05-12 & 01-05-14 \\
\hline GeP\&CO_H & 01-07-09 & 01-07-16 & $01-07-24$ & 01-08-03 & 01-08-10 & 01-08-12 \\
\hline GeP\&CO_I & $01-10-03$ & $01-10-10$ & 01-10-18 & $01-10-30$ & 01-11-04 & $01-11-07$ \\
\hline GeP\&CO_J & 02-01-01 & 02-01-09 & $02-01-17$ & $02-01-29$ & $02-02-03$ & $02-02-06$ \\
\hline GeP\&CO_K & $02-03-30$ & 02-04-07 & $02-04-15$ & $02-04-26$ & $02-05-01$ & $02-05-04$ \\
\hline GeP\&CO_L & $02-06-25$ & 02-07-02 & $02-07-11$ & $02-07-24$ & $02-07-30$ & $02-08-02$ \\
\hline
\end{tabular}




\section{Legends of figures}

Fig. 1.- Positions of observations used in this work, from the $12 \mathrm{GeP} \& \mathrm{CO}$ cruises. Indications refer to the oceanic provinces defined by Longhurst (1999): North Atlantic Drift Province (NADR), Gulf Stream (GFST), Caribbean Sea (CARB), Pacific North Equatorial Countercurrent (PNEC), Pacific Equatorial Divergence (PEQD), South Pacific Subtropical Gyre (SPSG) and Archipelagic Deep Basins (ARCH).

Fig. 2.- Comparisons of GeP\&CO measurements of mono- and divinyl chlorophyll a by spectrofluorometry and by HPLC with HPLC measurements at the Laboratoire d'Océanographie de Villefranche sur mer. For this test, three filtrations were made on 24 seawater samples taken during the GeP\&CO cruise K.

Fig. 3.- Time variations detected by GeP\&CO cruises in NADR. Plots correspond to average values of $\sim 12$ observations at the sea surface in this province for each cruise. From top to bottom: first panel, total chlorophyll a (Tchla, bold line), percentage of divinyl-chlorophyll a (\%dChla, thin line), concentration of fucoxanthin (Fuco, bold dotted line, multiplied by 10) and zeaxanthin (Zeax, thin dotted line, multiplied by 10); second panel, sea surface temperature (SST, bold dotted line), concentrations of nitrate $\left(\mathrm{NO}_{3}\right.$, bold line), silicate $\left(\mathrm{SiO}_{2}\right.$, thin line) and phosphate $\left(\mathrm{PO}_{4}\right.$, thin dotted line, multiplied by 10$)$; third panel, pigmentsestimated contribution of picoplankton (black), nanoplankton (gray) and microplankton (white) to total chlorophyll $a$ (pie charts), cell numbers of picoeucaryotes (Peu, bold line), and Synechococcus (Syn, thin line).

Fig. 4: Average coccolithophore standing stocks and concentrations of 19 'hexanoyloxyfucoxanthin (19'HF) in the NADR (top) and GFST (bottom) provinces. The vertical error bars are the standard deviation of estimates of total standing stocks.

Fig. 5.- Time variations detected by GeP\&CO cruises in GFST. Plots correspond to average values of $\sim 11$ observations at the sea surface in this province for each cruise. Symbols and scales are the same as in Figure 3. 
Fig. 6.- Time variations detected by GeP\&CO cruises in CARB. Plots correspond to average values of $\sim 7$ observations at the sea surface in this province for each cruise. Symbols and scales are the same as in Figure 3. Note : the vertical scale for Synechococcus and picoeucaryotes is in thousands of cells $\mathrm{ml}^{-1}$.

Fig. 7.- Time variations detected by GeP\&CO cruises in PNEC. Plots correspond to average values of $\sim 8$ observations at the sea surface in this province for each cruise. Symbols and scales are the same as in Figure 3.

Fig. 8: Average coccolithophore standing stocks and concentrations of 19'hexanoyloxyfucoxanthin (19'HF) in the PNEC (top), PEQD (middle) and SPSG (bottom) provinces. The vertical error bars are the standard deviation of estimates of total standing stocks.

Fig. 9.- Time variations detected by GeP\&CO cruises in PEQD. Plots correspond to average values of $\sim 22$ observations at the sea surface in this province for each cruise. Symbols and scales are the same as in Figure 3. Note : the vertical scale for picoeucaryotes and Synechococcus is in thousands of cells $\mathrm{ml}^{-1}$.

Fig. 10.- Time variations detected by GeP\&CO cruises in SPSG. Plots correspond to average values of $\sim 15$ observations at the sea surface in this province for each cruise. Symbols and scales are the same as in Figure 3. Note : the vertical scale for picoeucaryotes and Synechococcus is in thousands of cells $\mathrm{ml}^{-1}$.

Fig. 11.- Time variations detected by GeP\&CO cruises in ARCH. Plots correspond to average values of $\sim 7$ observations at the sea surface in this province for each cruise. Symbols and scales are the same as in Figure 3.

Fig. 12.- Chlorophyll versus nitrate concentration in the North Atlantic (open squares) and in oligotrophic provinces (solid circles) compared to the HNLC Pacific equatorial divergence (solid squares). 
Fig. 13: Distribution of coccolithophore species (weight \%) across the North Atlantic (top, boreal spring 2000) and Pacific (bottom, boreal winter 2000) in surface water along the GeP\&CO route. The grey box refer to the regions not considered in the present study (outside the core of NADR, GFST, PEQD and SPSG provinces).

Fig. 14: Comparative records of coccolithophore standing stocks, biovolumes and 19'HF concentrations along the GeP\&CO route across the Pacific during the boreal winter 2000 (a). The grey box refers to the region not considered in the present study (outside the core of PEQD and SPSG provinces). Lack of correlation in the PEQD region between standing stocks of coccolithophores and $19^{\prime} \mathrm{HF}$ concentrations is highlighted in the scatter-plot (b). 


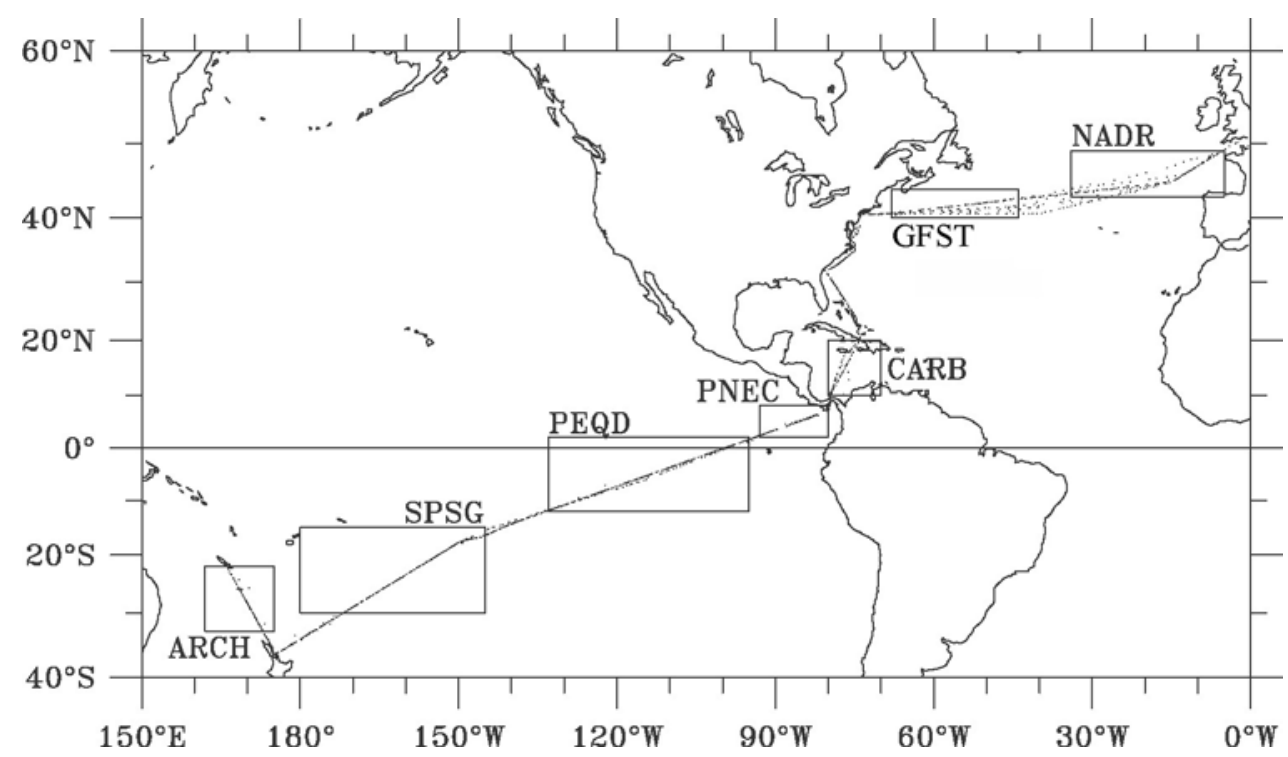

Fig. 1.- Positions of observations used in this work, from the $12 \mathrm{GeP} \& \mathrm{CO}$ cruises. Indications refer to the oceanic provinces defined by Longhurst (1999): North Atlantic Drift Province (NADR), Gulf Stream (GFST), Caribbean Sea (CARB), Pacific North Equatorial Countercurrent (PNEC), Pacific Equatorial Divergence (PEQD), South Pacific Subtropical Gyre (SPSG) and Archipelagic Deep Basins (ARCH). 

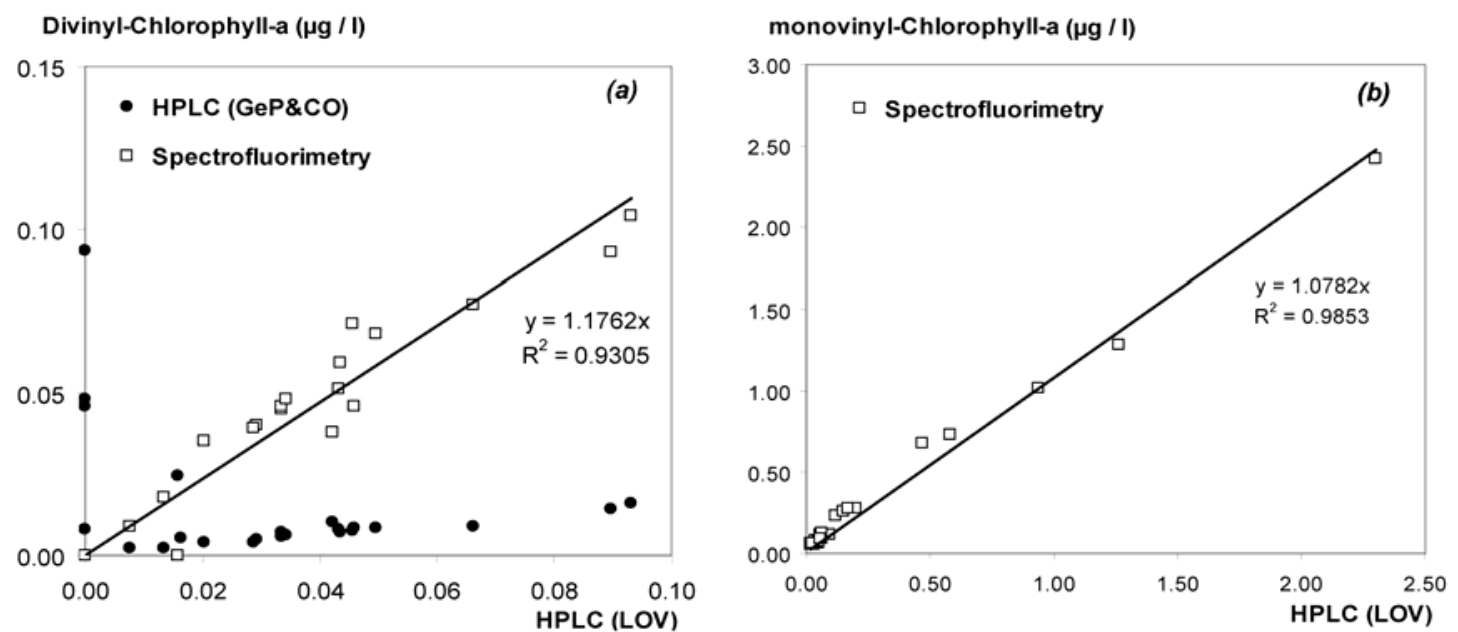

Fig. 2.- Comparisons of GeP\&CO measurements of mono- and divinyl chlorophyll a by spectrofluorometry and by HPLC with HPLC measurements at the Laboratoire d'Océanographie de Villefranche sur mer. For this test, three filtrations were made on 24 seawater samples taken during the GeP\&CO cruise $\mathrm{K}$. 

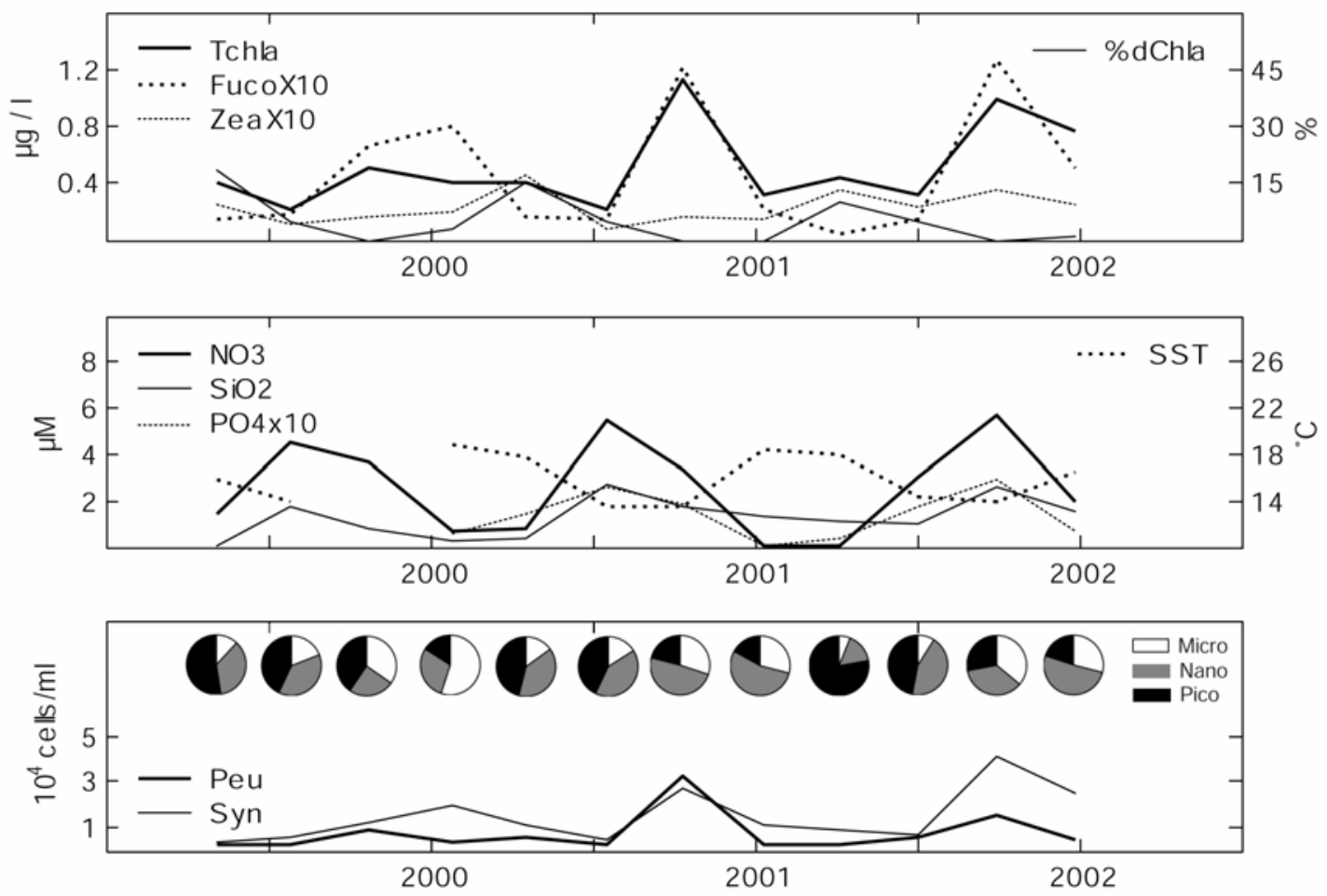

Fig. 3.- Time variations detected by GeP\&CO cruises in NADR. Plots correspond to average values of $\sim 12$ observations at the sea surface in this province for each cruise. From top to bottom: first panel, total chlorophyll a (Tchla, bold line), percentage of divinyl-chlorophyll a (\%dChla, thin line), concentration of fucoxanthin (Fuco, bold dotted line, multiplied by 10) and zeaxanthin (Zeax, thin dotted line, multiplied by 10); second panel, sea surface temperature (SST, bold dotted line), concentrations of nitrate $\left(\mathrm{NO}_{3}\right.$, bold line), silicate $\left(\mathrm{SiO}_{2}\right.$, thin line) and phosphate $\left(\mathrm{PO}_{4}\right.$, thin dotted line, multiplied by 10); third panel, contribution of picoplankton (black), nanoplankton (gray) and microplankton (white) to total chlorophyll a (pie charts), cell numbers of picoeucaryotes (Peu, bold line), and Synechococcus (Syn, thin line). 

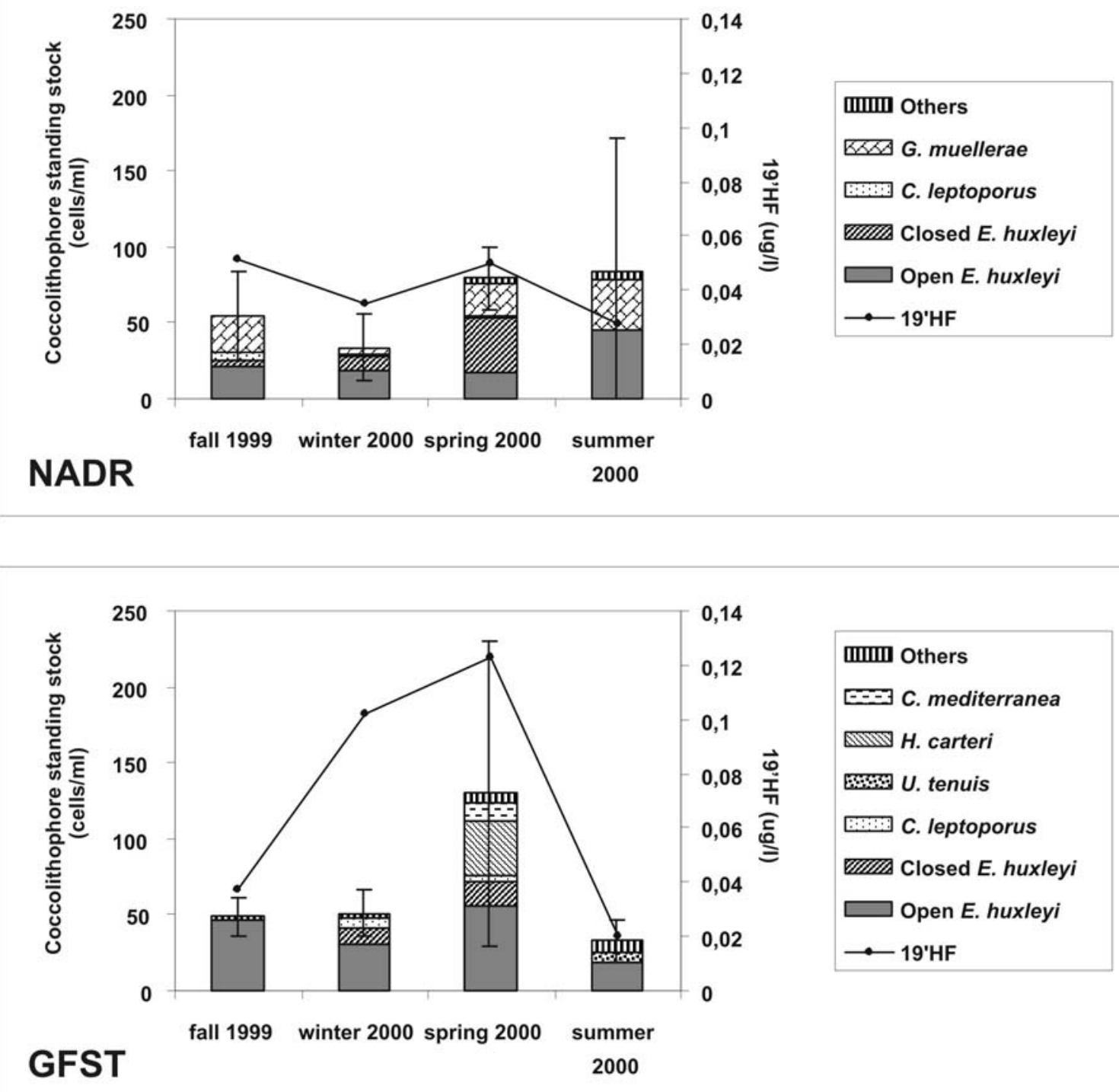

Fig. 4: Average coccolithophore standing stocks and concentrations of 19 'hexanoyloxyfucoxanthin (19'HF) in the NADR (top) and GFST (bottom) provinces. The vertical error bars are the standard deviation of estimates of total standing stocks. 

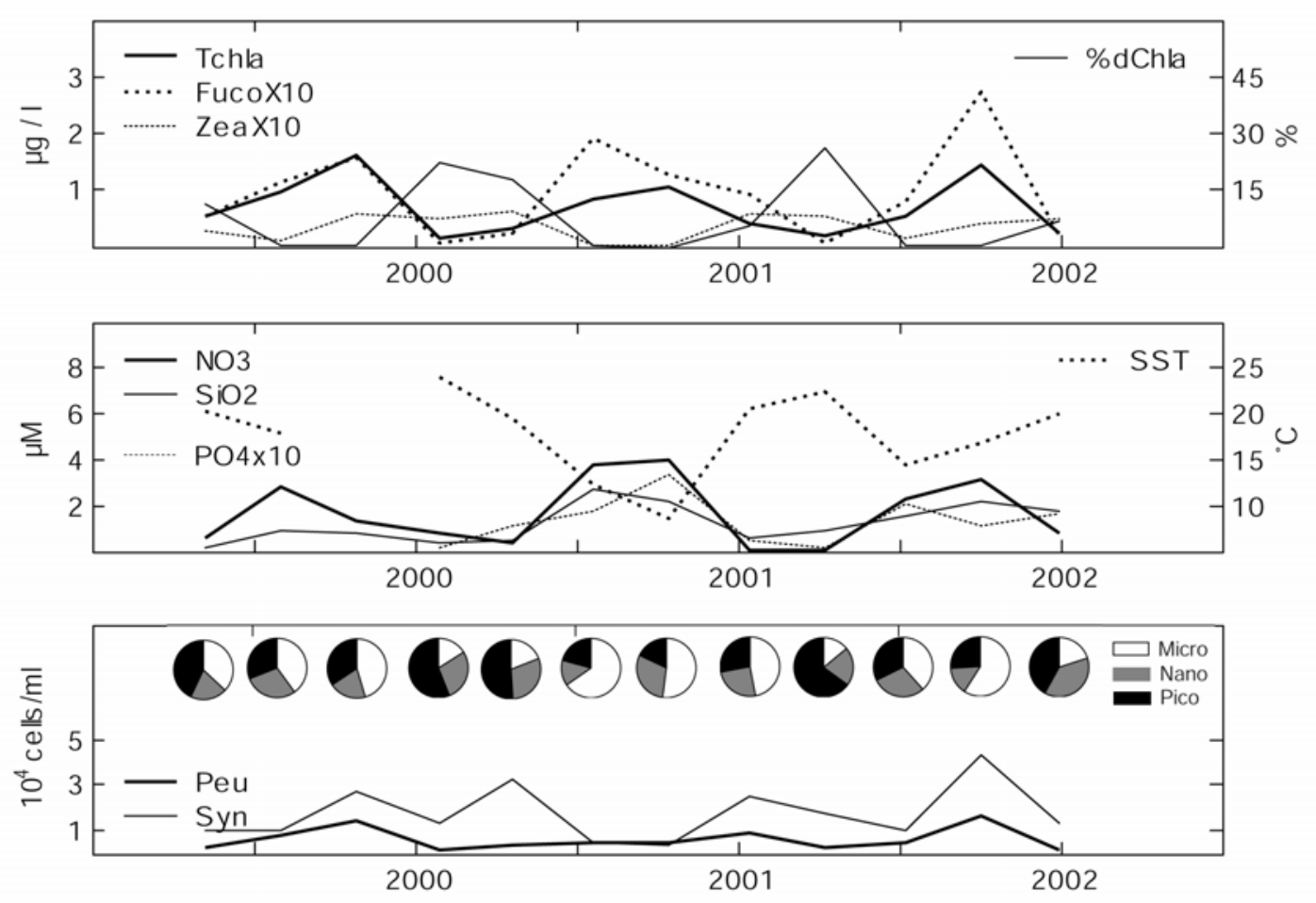

Fig. 5.- Time variations detected by GeP\&CO cruises in GFST. Plots correspond to average values of $\sim 11$ observations at the sea surface in this province for each cruise. Symbols and scales are the same as in Figure 3. 

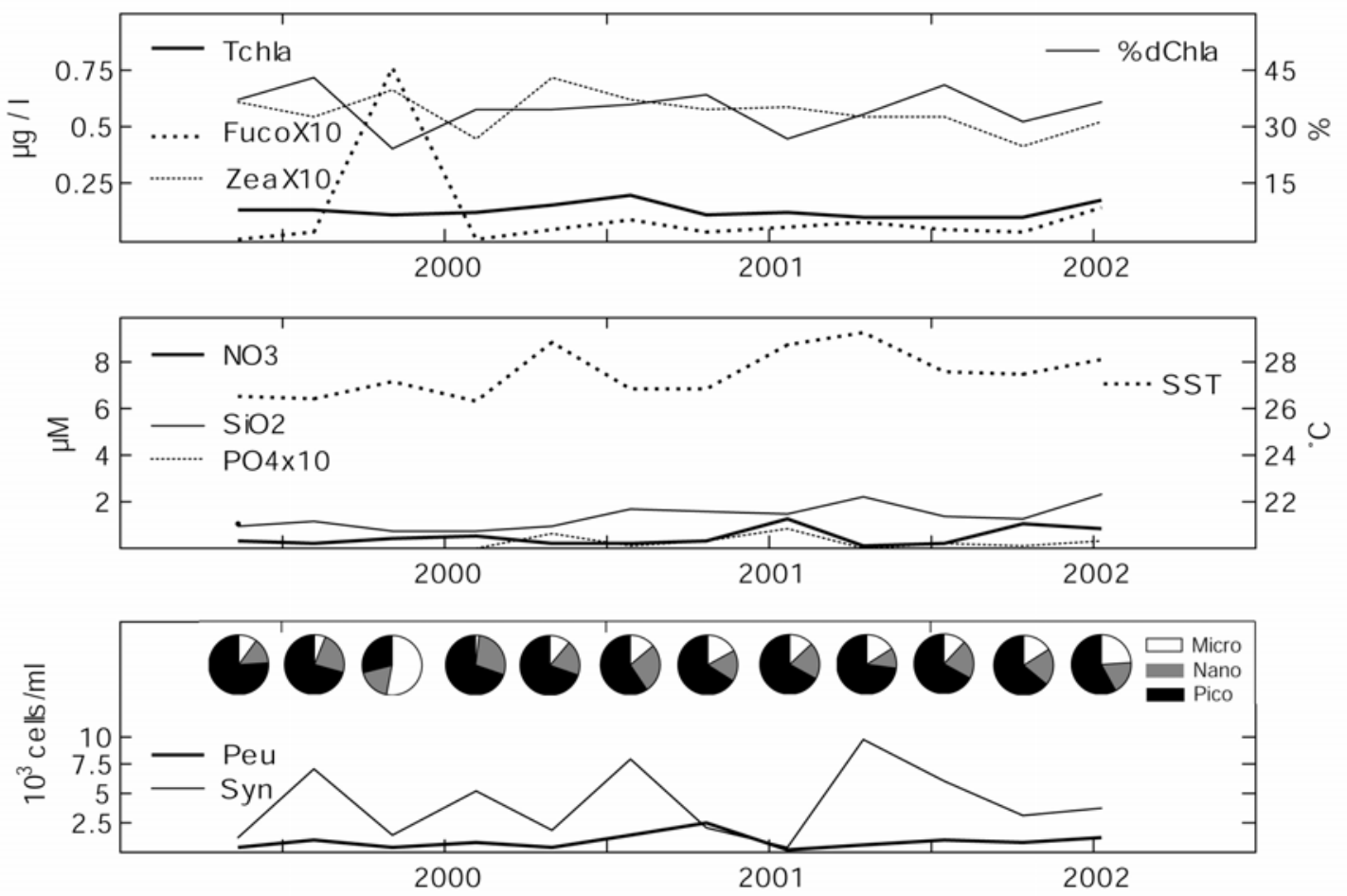

Fig. 6.- Time variations detected by GeP\&CO cruises in CARB. Plots correspond to average values of $\sim 7$ observations at the sea surface in this province for each cruise. Symbols and scales are the same as in Figure 3. Note : the vertical scale for Synechococcus and picoeucaryotes is in thousands of cells $\mathrm{ml}^{-1}$. 

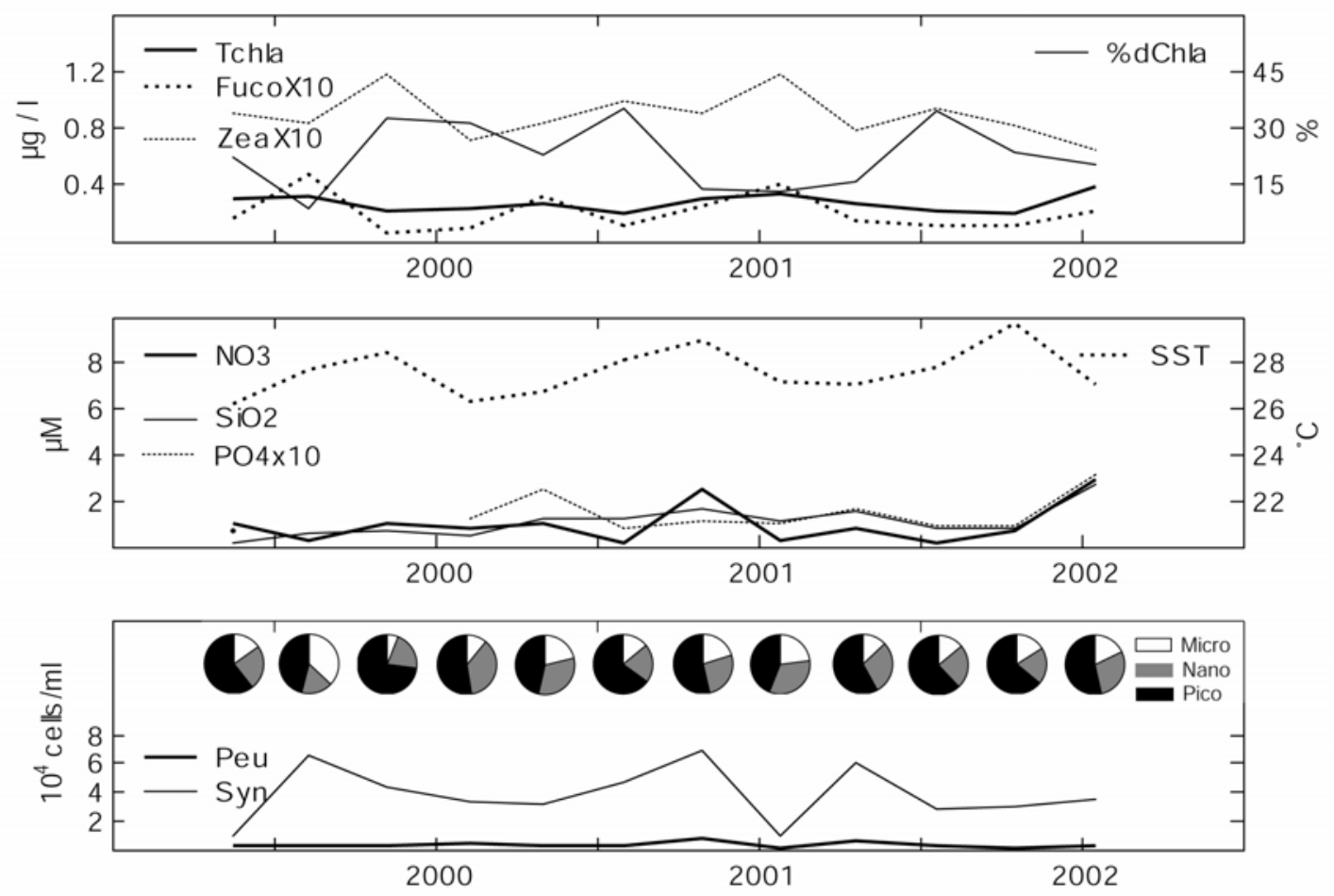

Fig. 7.- Time variations detected by GeP\&CO cruises in PNEC. Plots correspond to average values of $\sim 8$ observations at the sea surface in this province for each cruise. Symbols and scales are the same as in Figure 3. 

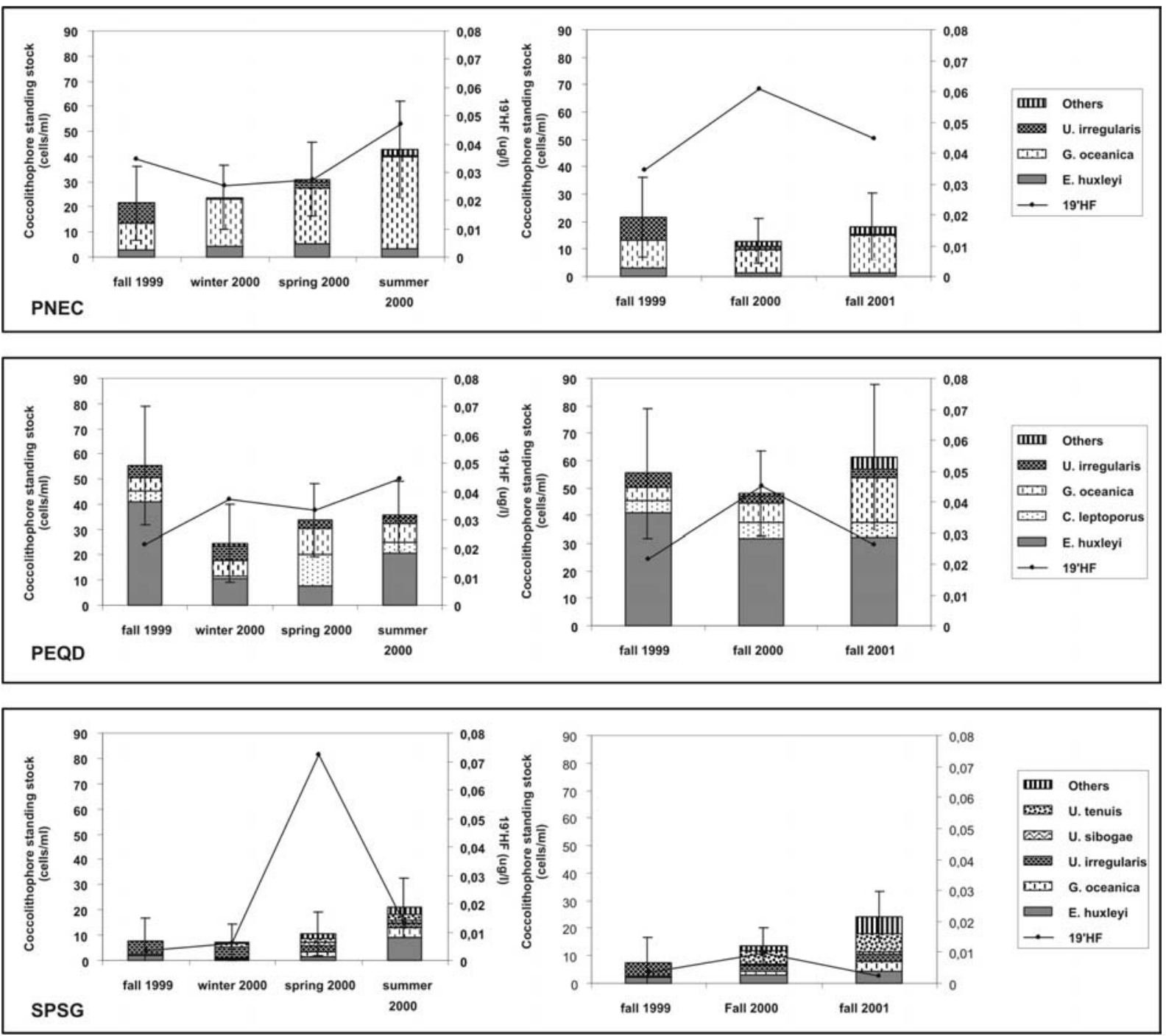

Fig. 8: Average coccolithophore standing stocks and concentrations of 19'hexanoyloxyfucoxanthin (19'HF) in the PNEC (top), PEQD (middle) and SPSG (bottom) provinces. The vertical error bars are the standard deviation of estimates of total standing stocks. 

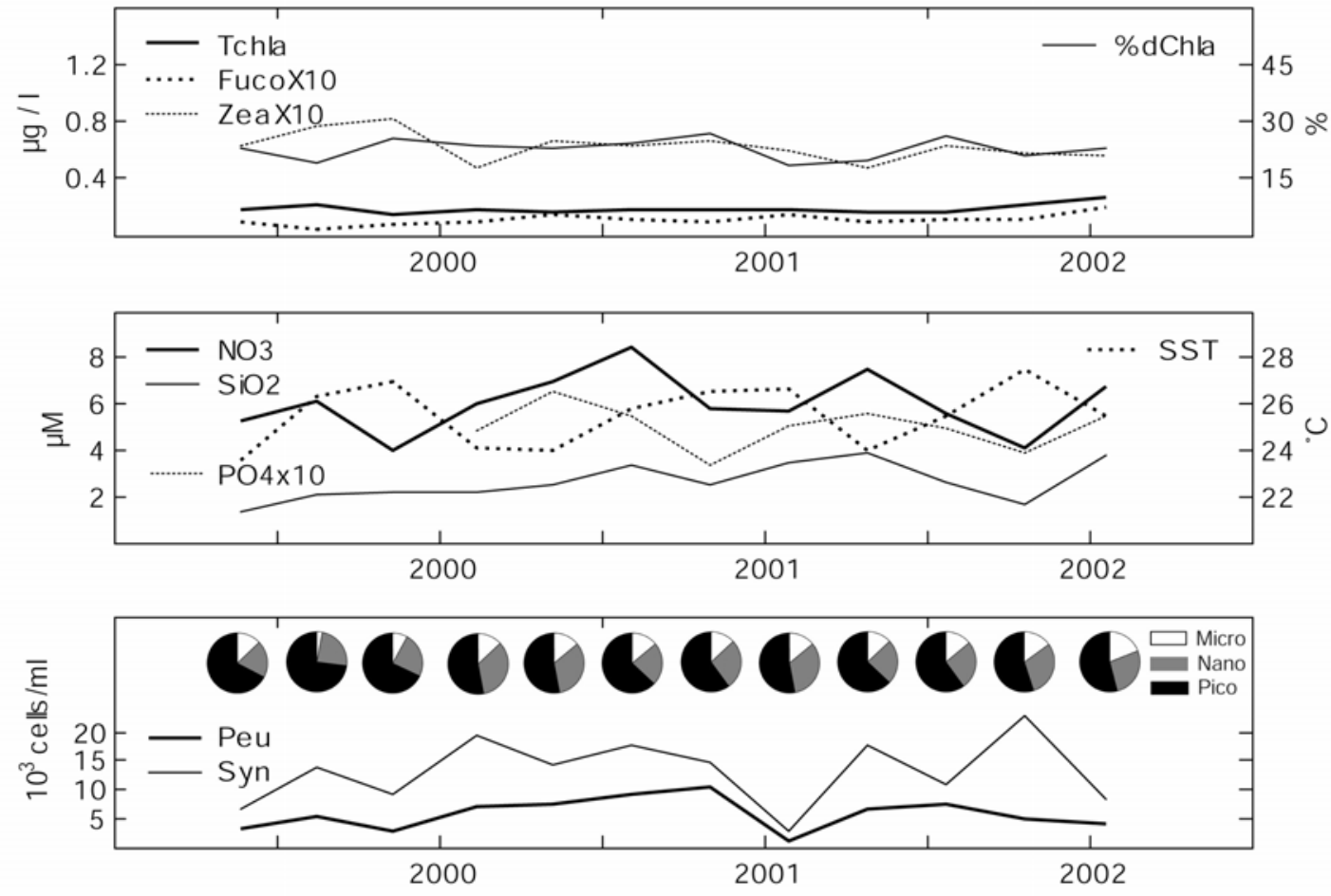

Fig. 9.- Time variations detected by GeP\&CO cruises in PEQD. Plots correspond to average values of $\sim 22$ observations at the sea surface in this province for each cruise. Symbols and scales are the same as in Figure 3. Note : the vertical scale for picoeucaryotes and Synechococcus is in thousands of cells $\mathrm{ml}^{-1}$. 

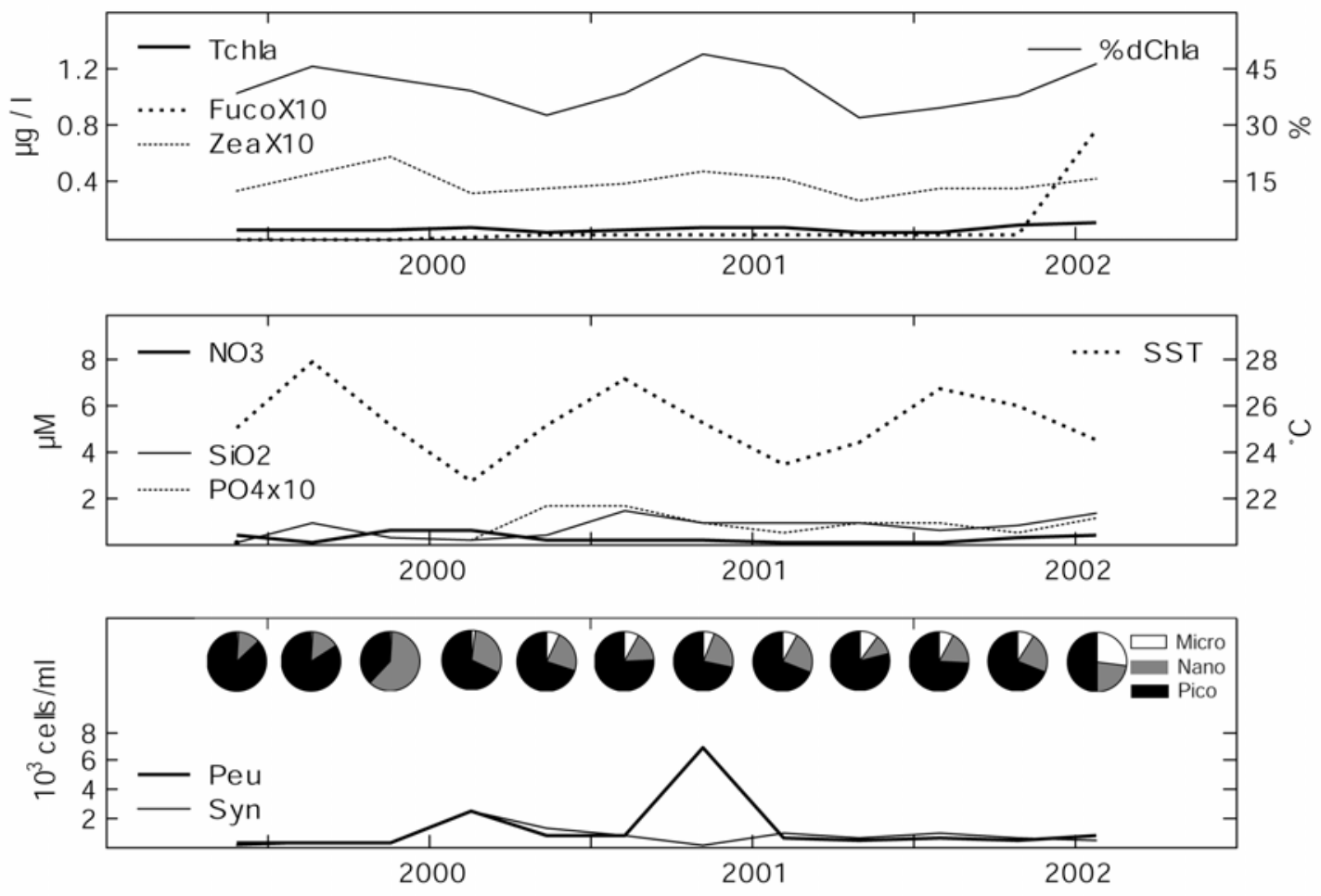

Fig. 10.- Time variations detected by GeP\&CO cruises in SPSG. Plots correspond to average values of $\sim 15$ observations at the sea surface in this province for each cruise. Symbols and scales are the same as in Figure 3. Note : the vertical scale for picoeucaryotes and Synechococcus is in thousands of cells $\mathrm{ml}^{-1}$. 

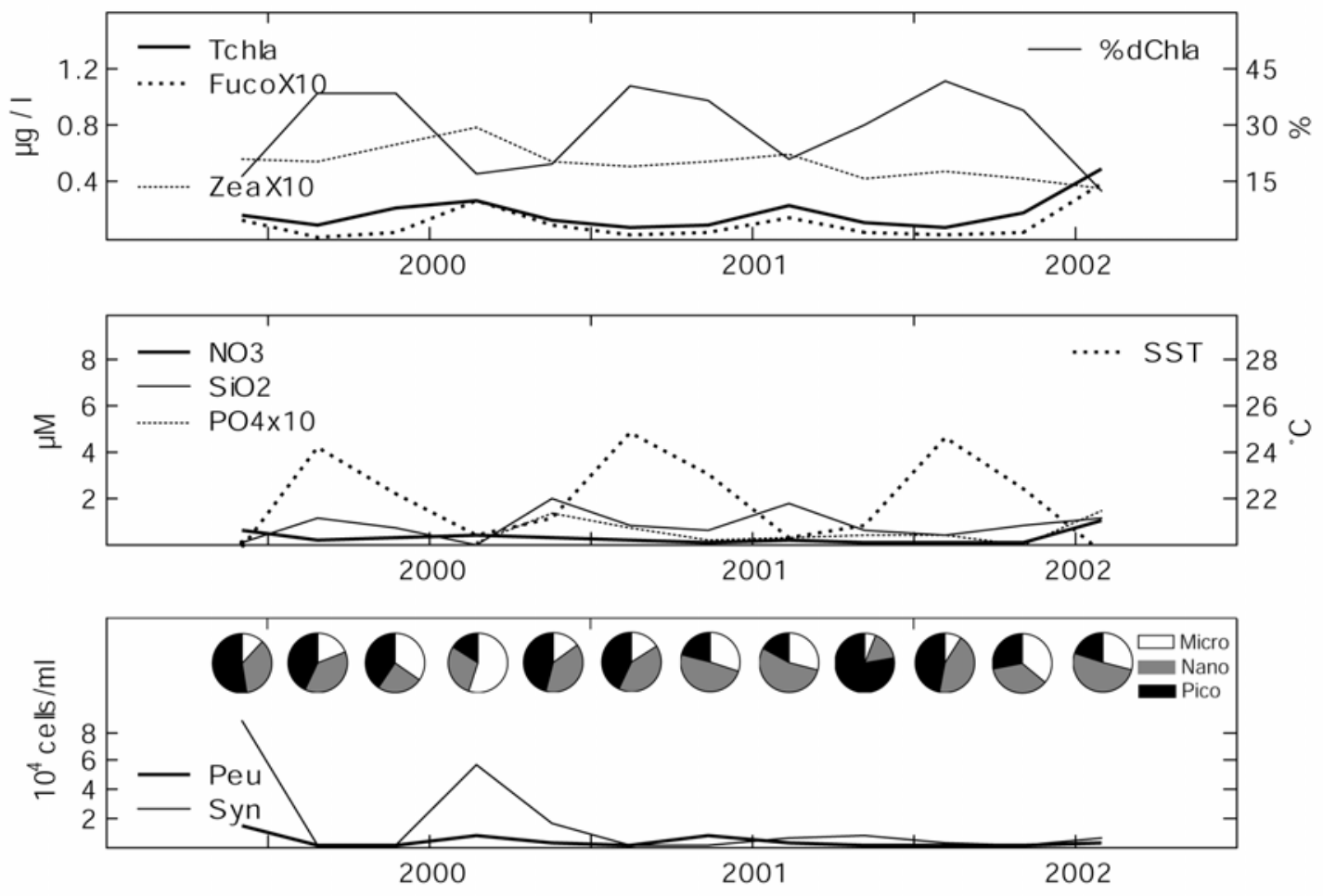

Fig. 11.- Time variations detected by GeP\&CO cruises in ARCH. Plots correspond to average values of $\sim 7$ observations at the sea surface in this province for each cruise. Symbols and scales are the same as in Figure 3. 
Tchla $(\mu \mathrm{g} / \mathrm{I})$

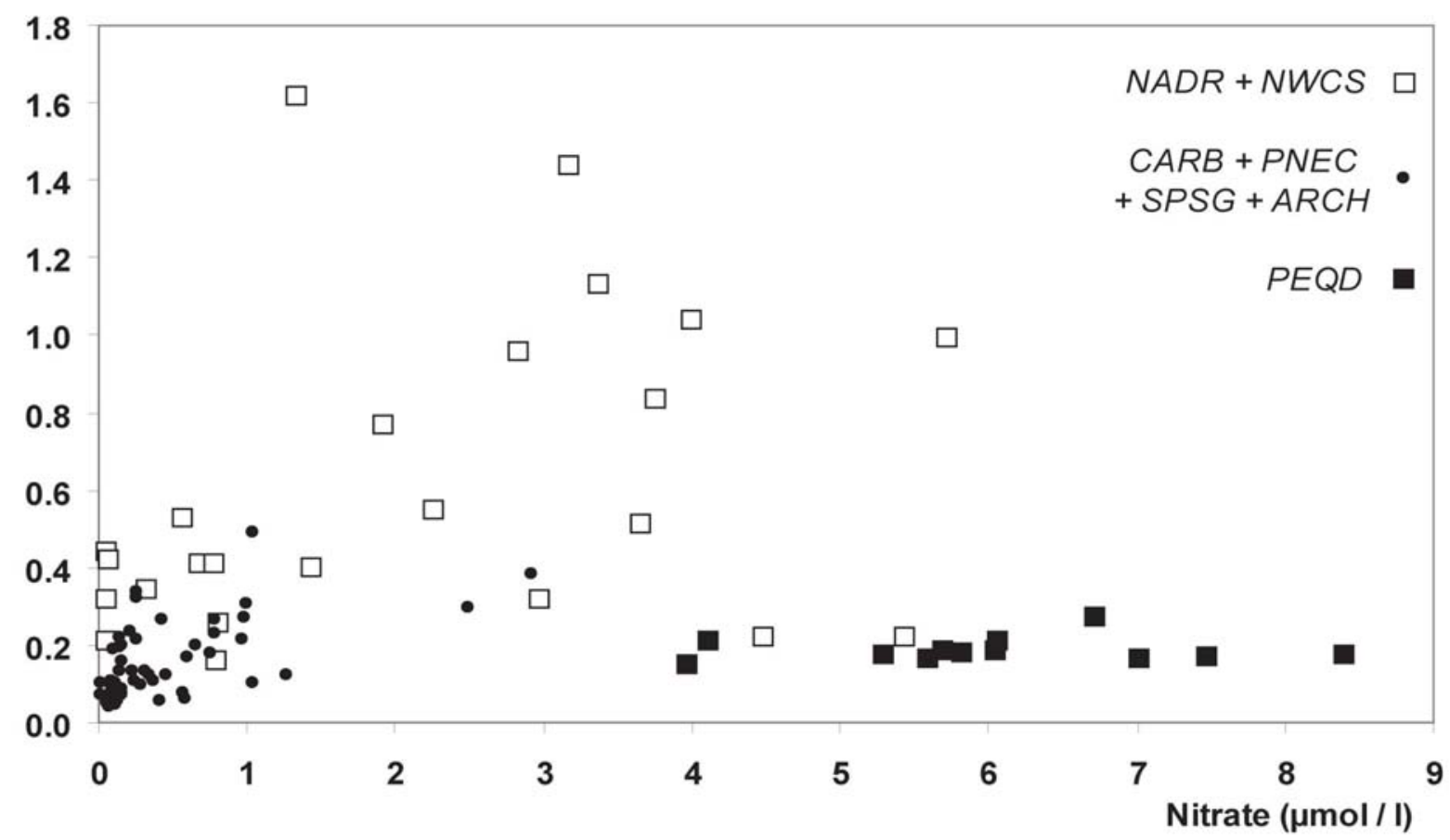

Fig. 12.- Chlorophyll versus nitrate concentration in the north Atlantic (open squares) and in oligotrophic provinces (solid circles) compared to the HNLC Pacific equatorial divergence (solid squares). 

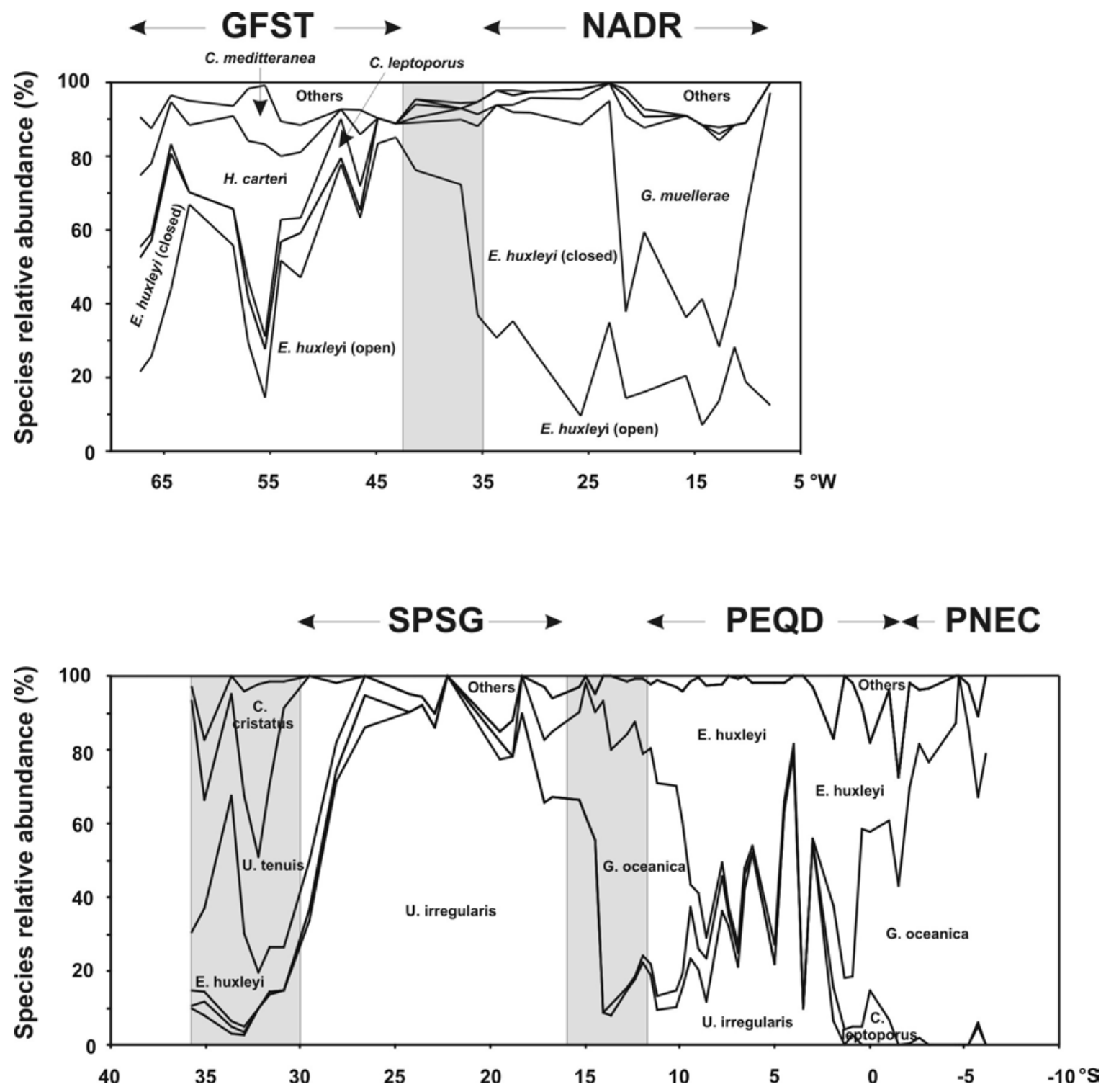

Fig. 13: Distribution of coccolithophore species (weight \%) across the North Atlantic (top, boreal spring 2000) and Pacific (bottom, boreal winter 2000) in surface water along the GeP\&CO route. The grey box refer to the regions not considered in the present study (outside the core of NADR, GFST, PEQD and SPSG provinces). 
( a )

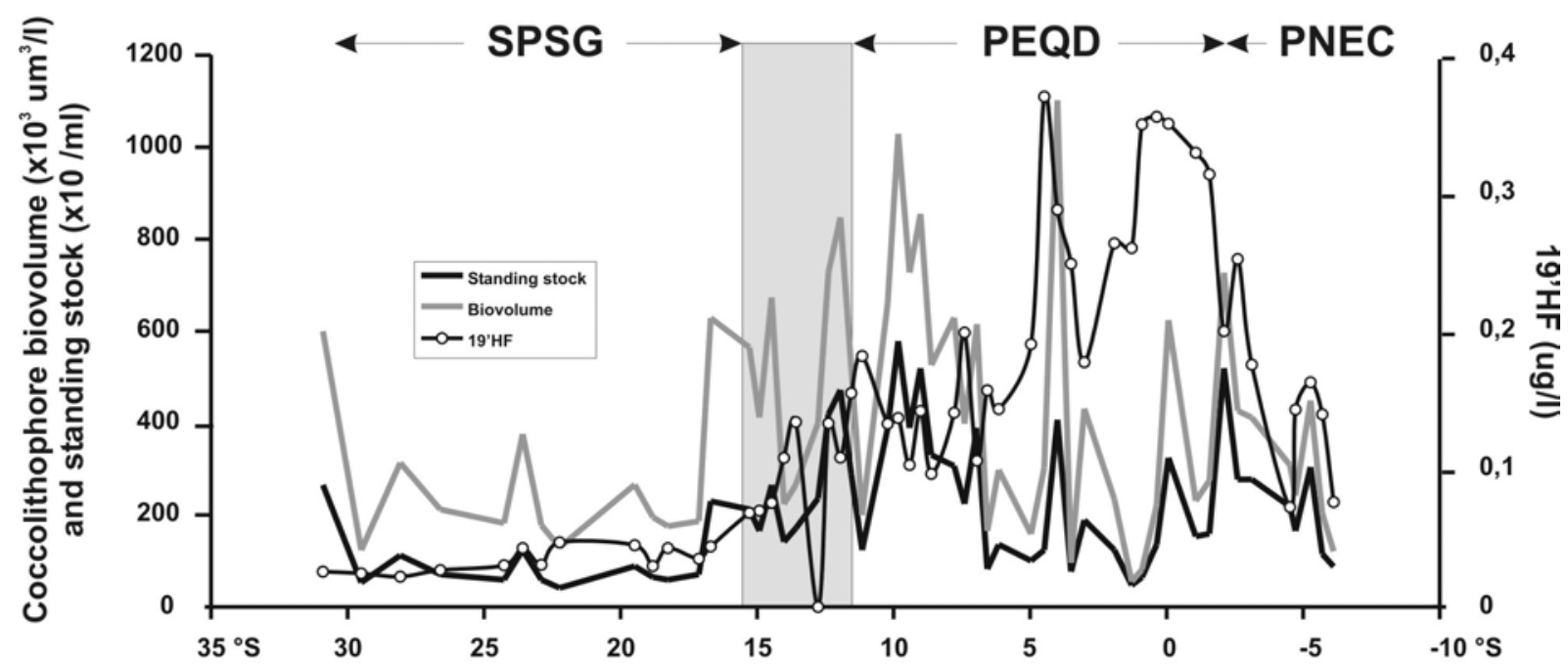

(b)

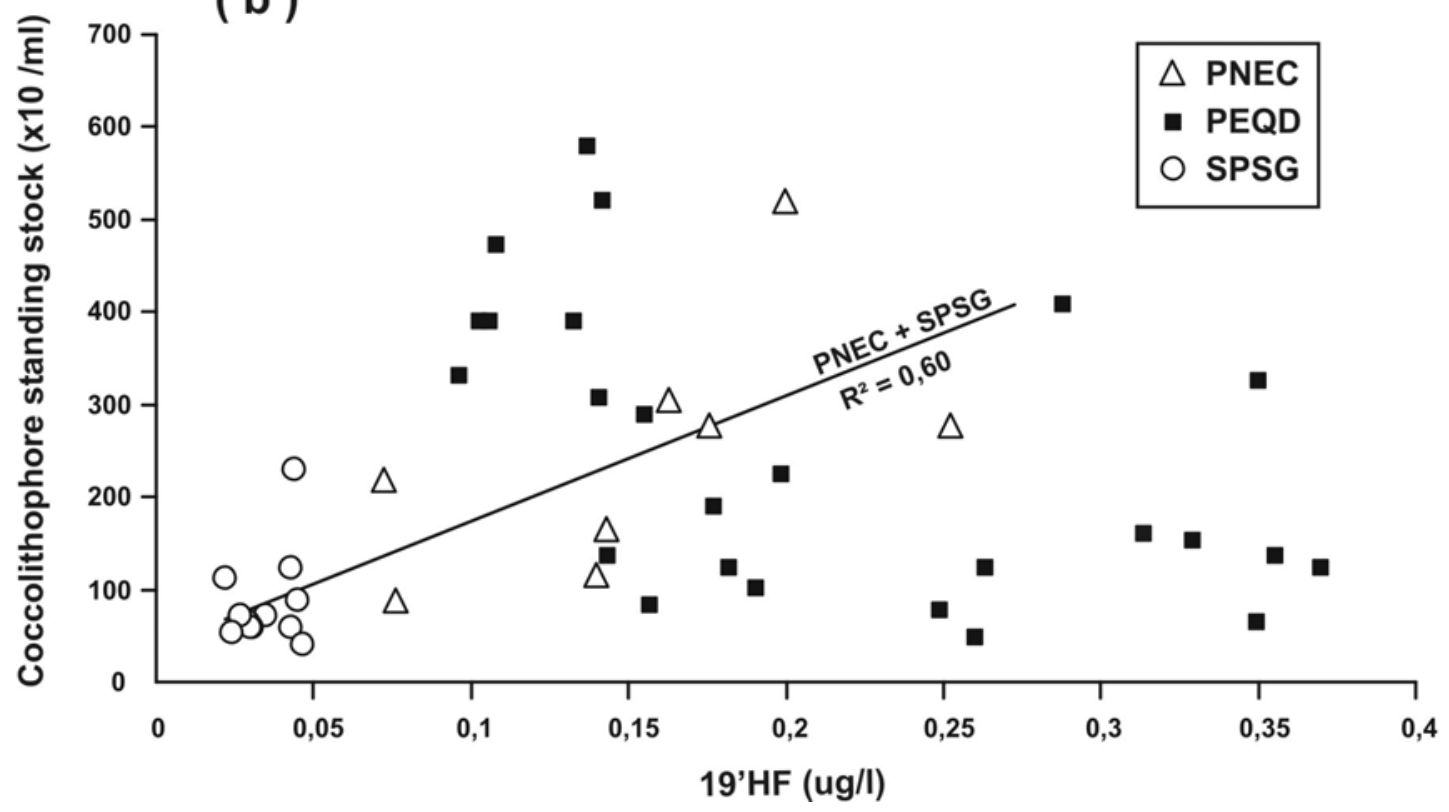

Fig. 14: Comparative records of coccolithophore standing stocks, biovolumes and 19'HF concentrations along the GeP\&CO route across the Pacific during the boreal winter 2000 (a). The grey box refers to the region not considered in the present study (outside the core of PEQD and SPSG provinces). The lack of correlation in the PEQD region between coccolithophore standing stocks and $19^{\prime} \mathrm{HF}$ concentrations is highlighted in the scatter-plot (b). 